\title{
Genetic behavior for seed yield and yield components in sesame (Sesamum indicum L.) under normal irrigation and water stress conditions
}

\section{Comportamiento genético del rendimiento de semillas y componentes del rendimiento en sésamo} (Sesamum indicum L.) en condiciones normales de riego y estrés hídrico

\author{
Suzan Abd El- Latif Kamel Ibrahim; Mohamed Ali Abdelsatar; Mohamed Abd El-Raheem Ahmed ${ }^{1}$; Magdy M. \\ $\mathrm{Niazy}^{2}$ \\ *Corresponding author: mohamedtemraz1@yahoo.com \\ *https://orcid.org/0000-0003-0780-1444

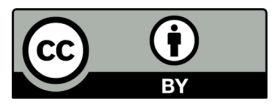

\begin{abstract}
Six divergent genotypes of sesame (Sesamum indicum L.) were crossed using a half diallel excluding reciprocal crosses, to estimate heterosis, combining ability and nature of gene action for studied traits under two irrigation regimes. The two irrigation regimes were normal irrigation conditions with amount of applied water $5952.38 \mathrm{~m}^{3} / \mathrm{ha}$ and water stress conditions with amount of applied water $2976.19 \mathrm{~m}^{3} / \mathrm{ha}$ at Etay-El-Baroud Agricultural Research Station, Behaira governorate, Agricultural Research Center, Egypt during 2019 summer season. A randomized complete block design with three replications was used for each irrigation regimes. The variation of genotypes and their components from parents, crosses and parents versus crosses were highly significant for all studied traits under both irrigation regimes and their interactions with irrigation. Variation attributable to general and specific combining ability was highly significant for seed yield and yield components under both irrigation regimes. The parents L92 and L110 were the best combiners for seed weight per plant and most of its components under both irrigation regimes. The best $\mathrm{F}_{1}$ cross combination was L92 $\times$ L110 in specific combining ability and heterotic effects over mid- and better-parents under both irrigation regimes for seed weight per plant and most of its attributes. The preponderance of additive gene action in the inheritance of most studied traits was observed, that further confirmed by its significance and the value of average degree of dominance exceeding the unity. Narrow-sense heritability varied from 0.19 for number of branches per plant to 0.47 for 1000 seed weight under normal irrigation, whereas, under water stress conditions, it ranged from 0.14 for number of branches per plant to 0.42 for fruiting zone length. Parents L95 and L93 under normal irrigation and L93 and L110 under water stress conditions carried mostly genes with dominant effects for seed weight per plant, in contrary, L92 and L110 under normal irrigation and L92 and L12 under water stress conditions carried mostly recessive alleles for seed weight per plant. Hence, the results will be used to develop a sesame breeding scheme at Etay-El-Baroud Agricultural Research Station.
\end{abstract}

Key words: Sesame, Sesamum indicum, Half diallel analysis, Heterosis, Combining ability, Gene action, Irrigation.

\section{Resumen}

Se cruzaron seis genotipos divergentes de sésamo (Sesamum indicum L.) utilizando un medio dialélico excluyendo cruces recíprocos, para estimar la heterosis, combinando la capacidad y la naturaleza de la acción de los genes para los rasgos estudiados bajo dos regímenes de riego. Los dos regímenes de riego fueron condiciones de riego normales con una cantidad de agua aplicada de 5952,38 m3/ha y condiciones de estrés hídrico con una cantidad de agua aplicada de 2976,19 m3/ha en la Estación de Investigación Agrícola de Etay-El-Baroud, gobernación de Behaira, Centro de Investigación Agrícola, Egipto durante 2019 temporada de verano. Se utilizó un diseño de bloques completos al azar con tres repeticiones para cada régimen de riego. La variación de genotipos y sus componentes de padres, cruces y padres versus cruces fue altamente significativa para todos los rasgos estudiados bajo ambos regímenes de riego y sus interacciones con el riego. La variación atribuible a la capacidad de combinación general y específica fue muy significativa para el rendimiento de semillas y los componentes del rendimiento en ambos regímenes de riego. Los padres

\footnotetext{
How to cite this article:

Ibrahim Suzan A. K., Abdelsatar, M. A., Ahmed, M. A., \& Niazy, M. M. (2021). Genetic behavior for seed yield and yield components in sesame (Sesamum indicum L.) under normal irrigation and water stress conditions. Peruvian Journal of Agronomy, 5(1), 1-17. http://dx.doi.org/10.21704/pja.v5i1.1656
}

\footnotetext{
${ }^{1}$ Oil Crops Research Department, Field Crops Research Institute, Agricultural Research Center, Giza, Egypt.

${ }^{2}$ Soils, Water and Environment Research Institute, ARC, Giza, Egypt
} 
L92 y L110 fueron los mejores combinadores para peso de semilla por planta y la mayoría de sus componentes bajo ambos regímenes de riego. La mejor combinación cruzada F1 fue L92 × L110 en capacidad de combinación específica y efectos heteróticos sobre padres medios y mejores bajo ambos regímenes de riego para el peso de semilla por planta y la mayoría de sus atributos. Se observó la preponderancia de la acción aditiva de genes en la herencia de los rasgos más estudiados, lo que se confirmó además por su importancia y el valor del grado medio de dominancia superior a la unidad. La heredabilidad en sentido estricto varió de 0,19 para el número de ramas por planta a 0,47 para el peso de 1000 semillas bajo riego normal, mientras que, en condiciones de estrés hídrico, varió de 0,14 para el número de ramas por planta a 0,42 para la longitud de la zona de fructificación. Los padres L95 y L93 bajo riego normal y L93 y L110 bajo condiciones de estrés hídrico portaban principalmente genes con efectos dominantes para el peso de semilla por planta, por el contrario, L92 y L110 bajo riego normal y L92 y L12 bajo condiciones de estrés hídrico portaban principalmente alelos recesivos para semilla peso por planta. Por lo tanto, los resultados se utilizarán para desarrollar un programa de mejoramiento de sésamo en la Estación de Investigación Agrícola de Etay-El-Baroud.

Palabras clave: Sésamo, Sesamum indicum, Análisis medio dialélico, Heterosis, Habilidad combinatoria, Acción genética, Irrigación.

\section{Introduction}

Sesame is one of the important oil crops in Egypt. It plays a vital and effective role in covering the requirements of oilseeds. To increase the productivity of its seeds, increased genetic diversity is necessary. Therefore, the ultimate goal of sesame breeder is to collect information on heterotic effects, per se performance, general and specific combining ability effects of parents along with genetic components of variance for yield and associated traits. The estimation of heterosis either of mid or better parents heterosis played a major role in identifies the desirable cross combinations in preferred direction. Moreover, combining ability analysis is a common biometrical tool in half diallel analysis to identify the best general combiners and the desirable specific cross combinations. Moreover, another method of half diallel analysis as Hayman (1954a, 1954b, and 1960) and Jinks (1954) provides the breeder with the detailed information on nature gene action and the genetic control in the studied traits. This information helps breeder in selection of preferred parents for future crosses at breeding programs to improve the sesame yield and related traits. For achieving this objective, the efforts in this study aimed to estimate: heterotic effects, combining ability effects, nature of gene action controlling genetic expression of the studied traits under both normal irrigation and water stress conditions.

\section{Materials and Methods}

\section{Plant materials}

Set of six parental sesame genotypes that had genetically distinct in their morphological traits were mated by a half-diallel mating design (excluding reciprocal crosses) during the 2018 summer season under Etay-El-Baroud/ Behaira Agricultural Research Station, Agricultural Research Center (ARC), Egypt, to create 15 single-cross combinations. These parental sesame genotypes were labeled as L95 (P1), L92 (P2), L28 (P3), L12 (P4), L93 (P5) and L110 (P6) during the hybridization program by a half-diallel mating design (Table 1). The source of these breeding materials was the Oil Crops Research Department, Field Crops Research Institute, ARC, Egypt.

The compositions and chemical properties of soil site samples were analyzed according to Jackson (1973) and are shown in Table 2. The wheat crop was sown in the field in the previous campaign. Our experiment was sown in the summer season $15^{\text {th }}$ June 2019.

Table 1. Name, pedigree and origin of sesame parental genotypes

\begin{tabular}{lccc}
\hline Parents & Name & Pedigree & Origin \\
\hline L95 & Introduce 432 & Unknown & USA 1976 \\
L92 & B-42 & Unknown & Egypt \\
L28 & Hybrid 133 & NA272 $\times$ Giza 32 & Egypt \\
L12 & Hybrid 102 & NA217 $\times$ Giza 25 & Egypt \\
L93 & Introduce 588 & Unknown & Mexico 1986 \\
L110 & Introduce 304 & Unknown & USA 1975 \\
\hline
\end{tabular}

Table 2. Soil composition and chemical properties of the upper $30 \mathrm{~cm}$ of the experimental soil for Etay-El-Baroud station

\begin{tabular}{lc|}
\hline \multicolumn{1}{c|}{$\begin{array}{c}\text { Soil properties } \\
\text { Composition }\end{array}$} & Value \\
\hline Sand (\%) & 16.75 \\
Silt (\%) & 34.85 \\
Clay (\%) & 48.40 \\
Soil texture & Clay \\
\hline \multicolumn{1}{c}{ Chemical analysis } & Value \\
\hline Concentration of $\mathrm{N}\left(\mathrm{mg} \mathrm{kg}^{-1}\right)$ & 156 \\
Concentration of $\mathrm{P}\left(\mathrm{mg} \mathrm{kg}^{-1}\right)$ & 7.89 \\
Concentration of $\mathrm{K}\left(\mathrm{mg} \mathrm{kg}^{-1}\right)$ & 374 \\
Electrical conductivity $(\mathrm{ds} / \mathrm{m})$ & 1.59 \\
$\mathrm{pH}$ & 7.46 \\
\hline
\end{tabular}

\section{Experimental design and cultural practices}

The field evaluation trial of the parents and their $F_{1}$ crosses was conducted in the summer season of 2019 under normal irrigation conditions (NI) with applied water amount of $5952.38 \mathrm{~m}^{3} / \mathrm{ha}$ and water stress conditions 
(WSC) with applied water amount of $2976.19 \mathrm{~m}^{3} / \mathrm{ha}$ using a randomized complete block design with three replicates for each irrigation regimes. Surface irrigation system was used through siphon pip with the rate of water flow $(3 \mathrm{~L} / \mathrm{s})$ to regulate and calculate the amount of applied water for each irrigation treatment. The distribution of the amount of applied water was based on the irrigation time taken for each treatment. Where, the irrigation time under WSC was half that of NI. Four irrigations were applied for each treatment.

The experimental plots consisted of two ridges, $5 \mathrm{~m}$ long and $60 \mathrm{~cm}$ wide, with a spacing of $10 \mathrm{~cm}$ between individual plants.

Seeds of parents and their $F_{1}$ crosses were hand-planted in adjacent plots. The sesame seedlings were thinned to keep one plant per hill on one side of the ridge.

The other cultural practices were done as recommended by Oil Crops Research Department, Field Crops Research Institute, ARC, Egypt.

\section{Data collection}

Ten plants were randomly taken from each plot to measure the average of plant height $(\mathrm{cm})$, fruiting zone length $(\mathrm{cm})$, capsules length $(\mathrm{cm})$, number of branches per plant, 1000 -seed weight $(\mathrm{g})$ and seed weight per plant $(\mathrm{g})$, which was adjusted to $15.5 \%$ seed moisture. Days to $50 \%$ flowering was recorded on a plot basis. Seed oil content (\%) was determined, after drying seed at $70^{\circ} \mathrm{C}$ for $48 \mathrm{~h}$, by the Soxhlet extraction technique, using diethyl ether (Association of Official Analytical Chemists [AOAC], 1990).

\section{Statistical analysis}

Combined analysis according to Steel et al. (1997) was performed for identifying irrigation effects on genetic variance and its components and the interaction between them, that after confirmed of homogeneity from the error variance.

Combining ability analysis for all studied traits was done according to method 2 model 1 of Griffing (1956) for each irrigation regimes. Moreover, analysis of Jones (1965) was performed for partitioning of dominance genetic effects (b) into three effects as $b_{1}$ which refers to test of mean deviation of $\mathrm{F}_{1}$ from their mid-parental values, $b_{2}$ which refers to test of whether mean dominance deviation of the $F_{1}$ from their mid- parental values within each array differs over arrays, and $b_{3}$ which refers to test of dominance deviation that is unique to each $\mathrm{F}_{1}$, for each irrigation regimes. To judge the gene action controlling all studied traits, baker ratio was done according to Baker (1978) as follow: $2 \mathrm{MS}_{\mathrm{gca}} /\left(2 \mathrm{MS}_{\mathrm{gca}}+\mathrm{Ms}_{\mathrm{sca}}\right)$. Heterosis was determined for individual crosses as the percentage deviation of $F_{1}$ means performance from either mid parents or better parents values at both irrigation regimes.
To determine the nature of dominance, the potence ratio as according to Wigan (1944) and Mather and Jinks (1971) was computed by the formulae: Potence ratio (P) $=\mathrm{F}_{1}-\mathrm{MP} / \mathrm{HP}-\mathrm{MP}$. Where $\mathrm{P}$ refers to relative potency of the gene set and $\mathrm{F}_{1}, \mathrm{MP}$ and HP are the means of the $\mathrm{F}_{1}$ generations, mid parents, and the higher parents, respectively. Complete dominance was indicated when $\mathrm{P}=+1$; while partial dominance is indicated when " $\mathrm{P}$ " is between $(-1$ and +1$)$, except the value zero, which indicates the absence of dominance. It is considered overdominance when potence ratio exceeds \pm 1 . The positive and negative signs indicate the direction of the dominance of either parent.

Hayman's diallel analysis (Hayman, 1954b) was performed to determine the genetic components and related genetic parameters. The adequacy of simple additivedominance model, and the proportion of dominant and recessive alleles in the sesame parental genotypes, along with degree of dominance under two irrigation regimes were determined by covariance (Wr)/variance (Vr) graph according to Jinks (1954), Hayman (1954a), and Mather and Jinks (1982). In addition, the adequacy of simple additive-dominance model was judged using three scaling tests: uniformity of $\mathrm{Wr}$ and $\mathrm{Vr}\left(\mathrm{t}^{2}\right.$-test), joint regression analysis, and variance analysis of $(\mathrm{Wr}+\mathrm{Vr})$ and $(\mathrm{Wr}-\mathrm{Vr})$ for all studied traits under two irrigation regimes. When the previous three tests are failure or inadequacy, the additivedominance model is completely invalid. However, the additive-dominance model is partially adequate, if one of these tests achieves the assumptions. Accordingly, partially adequate or completely adequate types can be considered as guide for extra analysis to determine the genetic components of variation (Johnson \& Askel, 1964; Wilson et al., 1978). MS-EXCEL (2007) with spreadsheet formula commands was used to conduct the statistical analyses and figures were elaborated in Excel, too in this study.

\section{Results and Discussion}

\section{Analysis of variance}

Highly significant genetic variability in respect to genotypes and its components of parents and their $F_{1}$ crosses were detected for all studied traits under both contrasting irrigation regimes (Tables 3 and 4) and their combined analysis. This indicated that existence of significant genetic variability among these populations, and hence increasing the chances of improving these traits. Similar results were obtained by Ramesh et al. (2014), Fahmy et al. (2015), Abd EL-Satar et al. (2016), Ismail et al. (2020) and Jeeva et al. (2020).

The considerable heterosis among created cross combinations was detected for all studied traits under both contrasting irrigation regimes as verified by highly significant parents $v s$. $\mathrm{F}_{1}$ crosses, as presented by Jones 
(1965) where $b_{1}$ refers to mean deviation of $\mathrm{F}_{1}$ 's from the mid-parents. Similarly, the high significance of $b_{2}$ values were obtained for all studied traits under both contrasting irrigation regimes, indicating asymmetry of gene distribution among parents used. Moreover, item $b_{3}$ was highly significant for all studied traits under contrasting irrigation regimes indicating interactions of allelic and non-allelic were inconsistent (Kearsy, 1965; Mather \& Jinks, 1971).

Irrigation regimes and their interaction with genotypes, parents, crosses and parents versus crosses in the combined analysis (Table 4) had highly significant effects on performance of all studied traits, indicating that irrigations had valuable environmental variability, which lead to difference of all population performance ranking from one irrigation to another. This could be attributed to providing plant with proper irrigation will help nutrients absorption from the soil which lead to increased vegetative growth and thereby increase metabolic rate and thus increase yield components, and consequently increasing seed weight per plant with compared to water stress conditions.

\section{Mean performance}

Mean performance of six parental sesame genotypes and their respective $15 \mathrm{~F}_{1}$ crosses for all studied traits are presented in Table $5 \mathrm{a}$ and $5 \mathrm{~b}$. In comparison with their parents, all cross combinations were earliness in flowering by $6.11 \%$ under NI and $5.86 \%$ under WSC and shorter in plant height by $8.29 \%$ at NI and $8.50 \%$ under WSC. Conversely, in comparison with their parents, the progress increase was observed in fruiting zone length by $40.99 \%$ under NI and $30.76 \%$ under WSC, capsules length by $18.91 \%$ under NI and $17.51 \%$ under WSC, number of branches per plant by $75.85 \%$ under NI and $77.89 \%$ under WSC, 1000 -seed weight by $27.36 \%$ under NI and $26.68 \%$ under WSC, seed weight per plant by $16.55 \%$ under NI and $30.48 \%$ under WSC and seed oil content by $2.51 \%$ under NI and $4.95 \%$ under WSC. This could be attributed to water stress

Table 3. Mean squares of the six sesame parents and their $\mathrm{F}_{1}$ crosses for earliness, yield and its attributes under normal irrigation(N) and water stress conditions (S) in 2019 season

\begin{tabular}{|c|c|c|c|c|c|c|c|c|c|}
\hline \multirow{2}{*}{$\begin{array}{l}\text { Source of } \\
\text { variance }\end{array}$} & \multirow{2}{*}{ df } & \multicolumn{2}{|c|}{ Days to $50 \%$ flowering } & \multicolumn{2}{|c|}{ Plant height } & \multicolumn{2}{|c|}{ Fruiting zone length } & \multicolumn{2}{|c|}{ Capsules length } \\
\hline & & $\mathbf{N}$ & $\mathbf{S}$ & $\mathbf{N}$ & $\mathbf{S}$ & $\mathbf{N}$ & $\mathbf{S}$ & $\mathbf{N}$ & S \\
\hline Replications & 2 & 0.33 & 0.11 & 9.35 & 13.29 & 1.53 & 1.33 & 0.00 & 0.02 \\
\hline Genotypes & 20 & $65.71 * *$ & $42.31 * *$ & $677.52 * *$ & $420.75 * *$ & $525.35 * *$ & $227.34 * *$ & $0.56^{* *}$ & $0.28 * *$ \\
\hline Parents (P) & 5 & $25.43^{* *}$ & $22.09 * *$ & $832.67 * *$ & $483.39 * *$ & $267.44 * *$ & $64.43^{* *}$ & $0.30 * *$ & $0.15^{* *}$ \\
\hline Crosses (C) & 14 & $70.82 * *$ & $45.36^{* *}$ & $545.02 * *$ & $350.52 * *$ & $353.38 * *$ & $186.05^{* *}$ & $0.47 * *$ & $0.21 * *$ \\
\hline P V C & 1 & $195.56 * *$ & $100.80 * *$ & $1756.67 * *$ & $1090.86^{* *}$ & $4222.48 * *$ & $1620.01 * *$ & $3.23 * *$ & $1.94 * *$ \\
\hline Error & 40 & 0.50 & 0.76 & 5.13 & 4.45 & 2.72 & 3.85 & 0.02 & 0.01 \\
\hline \multirow{2}{*}{$\begin{array}{l}\text { Source of } \\
\text { variance }\end{array}$} & \multirow[t]{2}{*}{ df } & \multicolumn{2}{|c|}{$\begin{array}{c}\text { Number of branches } \\
\text { per plant }\end{array}$} & \multicolumn{2}{|c|}{ 1000-seed weight } & \multicolumn{2}{|c|}{ Seed weight per plant } & \multicolumn{2}{|c|}{ Seed oil content } \\
\hline & & $\mathbf{N}$ & $\mathbf{S}$ & $\mathbf{N}$ & $\mathbf{S}$ & $\mathbf{N}$ & $\mathbf{S}$ & $\mathbf{N}$ & $\mathbf{S}$ \\
\hline Replications & 2 & 0.30 & 0.05 & 0.07 & 0.01 & 4.025 & 13.765 & 1.11 & 0.60 \\
\hline Genotypes & 20 & $5.58 * *$ & $3.04 * *$ & $1.28 * *$ & $0.63 * *$ & $82.764 * *$ & $87.773 * *$ & $9.24 * *$ & $15.83^{* *}$ \\
\hline Parents $(\mathrm{P})$ & 5 & $3.39 * *$ & $1.56^{* *}$ & $0.39 * *$ & $0.17 * *$ & $70.809 * *$ & $58.285^{* *}$ & $6.72 * *$ & $10.36^{* *}$ \\
\hline Crosses (C) & 14 & $2.18 * *$ & $1.31 * *$ & $1.09 * *$ & $0.47 * *$ & $65.251 * *$ & $61.070 * *$ & $9.64 * *$ & $13.60 * *$ \\
\hline P V C & 1 & $64.13 * *$ & $34.77 * *$ & $8.37 * *$ & $5.14 * *$ & $387.720 * *$ & $609.037 * *$ & $16.26^{* *}$ & $74.47 * *$ \\
\hline Error & 40 & 0.33 & 0.30 & 0.02 & 0.02 & 7.904 & 10.738 & 0.96 & 1.01 \\
\hline
\end{tabular}

Note: $*$, ** refers to significant at $5 \%$ and highly significant at $1 \%$, respectively

Table 4. Mean squares of the six sesame parents and their $F_{1}$ crosses for earliness, yield and its attributes traits across irrigation regimes in 2019 season

\begin{tabular}{lccccccccc}
\hline $\begin{array}{l}\text { Source of } \\
\text { variance }\end{array}$ & d.f & $\begin{array}{c}\text { Days } \\
\text { to 50\% } \\
\text { flowering }\end{array}$ & Plant height & $\begin{array}{c}\text { Fruiting } \\
\text { zone length }\end{array}$ & $\begin{array}{c}\text { Capsules } \\
\text { length }\end{array}$ & $\begin{array}{c}\text { Number of } \\
\text { branches } \\
\text { per plant }\end{array}$ & $\begin{array}{c}\text { 1000-seed } \\
\text { weight }\end{array}$ & $\begin{array}{c}\text { Seed weight } \\
\text { per plant }\end{array}$ & $\begin{array}{c}\text { Seed oil } \\
\text { content }\end{array}$ \\
\hline Irrigation (I) & 1 & $7344.79^{* *}$ & $29962.29^{* *}$ & $5034.01^{* *}$ & $8.26^{* *}$ & $49.53^{* *}$ & $15.65^{* *}$ & $2911.590^{* *}$ & $697.90^{* *}$ \\
Reps within I & 4 & 0.22 & 11.32 & 1.43 & 0.01 & 0.17 & 0.04 & 8.895 & 0.85 \\
Entries (E) & 20 & $22.31^{* *}$ & $268.75^{* *}$ & $175.53^{* *}$ & $0.20^{* *}$ & $1.98^{* *}$ & $0.44^{* *}$ & $39.642^{* *}$ & $4.73^{* *}$ \\
$\mathrm{E} \times \mathrm{I}$ & 20 & $85.71^{* *}$ & $829.52^{* *}$ & $577.17^{* *}$ & $0.65^{* *}$ & $6.65^{* *}$ & $1.47^{* *}$ & $130.894^{* *}$ & $20.34^{* *}$ \\
Parents (P) & 5 & $9.09^{* *}$ & $317.66^{* *}$ & $67.08^{* *}$ & $0.10^{* *}$ & $0.82^{*}$ & $0.13^{* *}$ & $29.598^{*}$ & $2.51^{*}$ \\
$\mathrm{P} \times \mathrm{I}$ & 5 & $38.43^{* *}$ & $998.40^{* *}$ & $264.78^{* *}$ & $0.34^{* *}$ & $4.12^{* *}$ & $0.43^{* *}$ & $99.496^{* *}$ & $14.57^{* *}$ \\
Crosses (C) & 14 & $23.47^{* *}$ & $220.33^{* *}$ & $127.93^{* *}$ & $0.15^{* *}$ & $0.80^{* *}$ & $0.35^{* *}$ & $28.484^{* *}$ & $4.43^{* *}$ \\
$\mathrm{C} \times \mathrm{I}$ & 14 & $92.71^{* *}$ & $675.21^{* *}$ & $411.50^{* *}$ & $0.52^{* *}$ & $2.69^{* *}$ & $1.22^{* *}$ & $97.837^{* *}$ & $18.80^{* *}$ \\
$\mathrm{P}$ vs C & 1 & $72.14^{* *}$ & $702.02^{* *}$ & $1384.17 * *$ & $1.27^{* *}$ & $24.17 * *$ & $3.33^{* *}$ & $246.079^{* *}$ & $20.04^{* *}$ \\
$\mathrm{P} \times \mathrm{F}_{1} \times \mathrm{I}$ & 1 & $224.21^{* *}$ & $2145.52^{* *}$ & $4458.32^{* *}$ & $3.90^{* *}$ & $74.73^{* *}$ & $10.18^{* *}$ & $750.678^{* *}$ & $70.69^{* *}$ \\
Error & 80 & 0.63 & 4.79 & 3.28 & 0.02 & 0.32 & 0.02 & 9.321 & 0.99 \\
\hline
\end{tabular}

Note: $* * *$ refers to significant at $5 \%$ and highly significant at $1 \%$, respectively 
led to a decrease in the rate of vegetative growth and thus a decrease in the rates of metabolism, thus reducing the movement of photosynthesis products from the leaves as a source to the seed as a sink, and this will negatively affect the yield components and thus seed weight per plant.

The earliest sesame parents in flowering were L12 (60.67 day) and L92 (61.67 day) under NI and L110 (44.00) and L12 (45.33) under WSC and their respective crosses L92 $\times$ L110 (51.33 day) and L12 $\times$ L110 (51.67 day) under NI and L92 $\times$ L110 (40.33 day) and L12 × L110 (40.67 day) under WSC. This indicated that genes responsible for earliness were passed to their $F_{1}$ crosses. As for plant height, the dwarfest the parents were L93 $(124.00 \mathrm{~cm})$ and L28 $(125.67 \mathrm{~cm})$ under NI and L28 $(96.00 \mathrm{~cm})$ and L93 $(97.00 \mathrm{~cm})$ under WSC and their $\mathrm{F}_{1}$ crosses L93 $\times$ L110 (109.00) under NI and L93 $\times$ L110 $(84.33 \mathrm{~cm})$ under WSC, again, genes of dwarfness in the parents passed into their $\mathrm{F}_{1}$ crosses. In case of fruiting zone length, the promising parents were L95 $(57.27 \mathrm{~cm}$ and $42.57 \mathrm{~cm})$ and L92 (53.00 and $37.52 \mathrm{~cm}$ ) under both NI and WSC, respectively and their $F_{1}$ cross combinations L95 $\times$ L92 $(82.67 \mathrm{~cm})$ and L95 $\times$ L28 $(82.67 \mathrm{~cm})$ under NI and L95 $\times$ L92 $(64.27 \mathrm{~cm})$ and L95 $\times$ L28 $(59.07 \mathrm{~cm})$ under WSC. This may be attributed to genes with positive effect on fruiting zone length transformed to their respective $\mathrm{F}_{1}$ crosses. The largest capsules length was detected in the parents L95 $(3.03 \mathrm{~cm})$ and L92 $(2.83 \mathrm{~cm})$ under NI and L95 $(2.45 \mathrm{~cm})$ and L12 $(2.39 \mathrm{~cm})$ under WSC and their genes with positive effect passed to the $\mathrm{F}_{1}$ crosses L95 $\times$ L93 $(3.83 \mathrm{~cm}$ and $3.24 \mathrm{~cm})$ and L95 $\times$ L28 $(3.77 \mathrm{~cm}$ and $3.11 \mathrm{~cm})$ under NI and WSC, respectively. The genes responsible for more branches/ plant passed from the parents as L92 (4.33 branch) and L12 (3.67 branch) under NI and L28 (3.00 branch) and L110 (2.67 branch) under WSC to their $\mathrm{F}_{1}$ crosses as L95 $\times$ L110 (7.00 branch) and L12 $\times$ L110 (6.00 branch) under NI and L95 $\times$ L110 (5.33 branch) and L95 $\times$ L12 (4.67 branch) under WSC. The positive effect of genes towards increasing 1000-seed weight transformed from the parents as L95 (3.47 $\mathrm{g}$ and $2.72 \mathrm{~g}$ ) and L92 (3.26 $\mathrm{g}$ and $2.58 \mathrm{~g}$ ) under NI and WSC, respectively to their $\mathrm{F}_{1}$ crosses as L95 $\times$ L92 (4.72 g) and L92 × L28 (4.61 g) under NI and L95 $\times$ L12 (3.80 g) and L95 $\times$ L110 (3.67 g) under WSC. The desirable genes effect on seed weight per plant passed from parents as L92 (41.54 $\mathrm{g}$ and $28.57 \mathrm{~g})$ and L110 (35.85 $\mathrm{g}$ and $25.17 \mathrm{~g})$ under NI and WSC, respectively to L92 $\times$ L110 (51.27 $\mathrm{g}$ and $37.53 \mathrm{~g}$ ) and L28 $\times$ L12 (45.16 $\mathrm{g}$ and $34.69 \mathrm{~g})$ under NI and WSC. The highest proportion of seed oil content was detected in the parents L110 (46.72 $\%)$ and L95 (45.84\%) under NI and L95 (52.32\%) and L12 (48.31\%) under WSC, which passed to their $\mathrm{F}_{1}$ crosses L92 $\times$ L12 (48.79 \%) and L95 $\times$ L110 (48.36\%) under NI and L95 $\times$ L92 (55.50 \%) and L92 $\times$ L12 (52.90\%) under WSC. This result corroborates with the findings of Fahmy et al. (2015), Abd EL-Satar et al. (2016), Ismail et al. (2020) and Jeeva et al. (2020), who observed significant genetic variations among parents and their $\mathrm{F}_{1}$ crosses for all studied traits.

Table 5a. Mean performance of six parental sesame genotypes and their $15 \mathrm{~F}_{1}$ cross combinations for days to $50 \%$ flowering, plant height, fruiting zone length and capsules length under normal irrigation $(\mathrm{N})$ and water stress conditions $(\mathrm{S})$ in 2019 season

\begin{tabular}{|c|c|c|c|c|c|c|c|c|}
\hline \multirow{2}{*}{ Genotypes } & \multicolumn{2}{|c|}{ Days to $50 \%$ flowering } & \multicolumn{2}{|c|}{ Plant height } & \multicolumn{2}{|c|}{ Fruiting zone length } & \multicolumn{2}{|c|}{ Capsules length } \\
\hline & $\mathbf{N}$ & $\mathbf{S}$ & $\mathbf{N}$ & $\mathbf{S}$ & $\mathbf{N}$ & $\mathbf{S}$ & $\mathbf{N}$ & S \\
\hline L95 & 65.67 & 49.33 & 165.67 & 128.67 & 57.27 & 42.57 & 3.03 & 2.45 \\
\hline L92 & 61.67 & 49.00 & 132.33 & 105.67 & 53.00 & 37.52 & 2.83 & 2.37 \\
\hline L28 & 68.33 & 51.33 & 125.67 & 96.00 & 38.00 & 37.41 & 2.17 & 1.88 \\
\hline L12 & 60.67 & 45.33 & 144.33 & 105.00 & 46.00 & 37.12 & 2.77 & 2.39 \\
\hline L93 & 62.00 & 47.67 & 124.00 & 97.00 & 37.00 & 36.12 & 2.70 & 2.14 \\
\hline L110 & 64.67 & 44.00 & 154.00 & 118.00 & 34.00 & 28.24 & 2.40 & 2.08 \\
\hline LSD $5 \%$ & 0.30 & 0.37 & 0.97 & 0.90 & 0.70 & 0.84 & 0.06 & 0.04 \\
\hline LSD $1 \%$ & 0.40 & 0.50 & 1.29 & 1.20 & 0.94 & 1.12 & 0.08 & 0.06 \\
\hline L95 × L92 & 61.33 & 42.67 & 139.00 & 107.00 & 82.67 & 64.27 & 3.37 & 2.53 \\
\hline $\mathrm{L} 95 \times \mathrm{L} 28$ & 60.00 & 45.67 & 157.33 & 120.00 & 82.67 & 59.07 & 3.77 & 3.11 \\
\hline $\mathrm{L} 95 \times \mathrm{L} 12$ & 68.33 & 52.67 & 122.67 & 94.33 & 75.67 & 56.75 & 3.47 & 2.74 \\
\hline L95 × L93 & 63.33 & 48.33 & 145.33 & 114.00 & 62.33 & 44.79 & 3.83 & 3.24 \\
\hline $\mathrm{L} 95 \times \mathrm{L} 110$ & 57.33 & 42.00 & 125.00 & 93.67 & 64.00 & 52.10 & 3.23 & 2.58 \\
\hline $\mathrm{L} 92 \times \mathrm{L} 28$ & 63.00 & 48.33 & 130.67 & 101.67 & 63.00 & 53.68 & 2.80 & 2.41 \\
\hline $\mathrm{L} 92 \times \mathrm{L} 12$ & 64.00 & 47.00 & 122.33 & 93.33 & 59.33 & 42.92 & 3.33 & 2.67 \\
\hline $\mathrm{L} 92 \times \mathrm{L} 93$ & 56.67 & 42.00 & 135.67 & 103.33 & 50.33 & 37.90 & 3.20 & 2.65 \\
\hline $\mathrm{L} 92 \times \mathrm{L} 110$ & 51.33 & 40.33 & 120.00 & 89.67 & 49.00 & 37.84 & 2.87 & 2.50 \\
\hline $\mathrm{L} 28 \times \mathrm{L} 12$ & 64.67 & 42.00 & 132.33 & 103.33 & 62.00 & 46.30 & 2.83 & 2.54 \\
\hline L28 $\times$ L93 & 64.33 & 46.00 & 122.00 & 92.00 & 63.67 & 45.55 & 2.83 & 2.54 \\
\hline $\mathrm{L} 28 \times \mathrm{L} 110$ & 57.67 & 51.33 & 146.00 & 113.00 & 53.67 & 42.08 & 2.43 & 2.30 \\
\hline $\mathrm{L} 12 \times \mathrm{L} 93$ & 56.33 & 44.00 & 122.00 & 93.00 & 54.33 & 45.07 & 2.73 & 2.30 \\
\hline $\mathrm{L} 12 \times \mathrm{L} 110$ & 51.67 & 40.67 & 110.33 & 85.00 & 49.33 & 40.12 & 3.20 & 2.41 \\
\hline $\mathrm{L} 93 \times \mathrm{L} 110$ & 59.00 & 41.67 & 109.00 & 84.33 & 63.00 & 47.37 & 3.37 & 2.60 \\
\hline LSD $5 \%$ & 0.48 & 0.59 & 1.53 & 1.42 & 1.11 & 1.32 & 0.10 & 0.07 \\
\hline LSD $1 \%$ & 0.64 & 0.79 & 2.04 & 1.90 & 1.49 & 1.77 & 0.13 & 0.09 \\
\hline
\end{tabular}


Table 5b. Mean performance of six parental sesame genotypes and their $15 \mathrm{~F}_{1}$ cross combinations for number of branches per plant, 1000 -seed weight, seed weight per plant and seed oil content under normal irrigation (N) and water stress conditions (S) in 2019 season

\begin{tabular}{|c|c|c|c|c|c|c|c|c|}
\hline \multirow{2}{*}{ Genotypes } & \multicolumn{2}{|c|}{$\begin{array}{c}\text { Number of branches } \\
\text { per plant }\end{array}$} & \multicolumn{2}{|c|}{1000 -seed weight } & \multicolumn{2}{|c|}{ Seed weight per plant } & \multicolumn{2}{|c|}{ Seed oil content } \\
\hline & $\mathbf{N}$ & $\mathrm{S}$ & $\mathbf{N}$ & $\mathrm{S}$ & $\mathbf{N}$ & $\mathrm{S}$ & $\mathbf{N}$ & $\mathrm{S}$ \\
\hline L95 & 1.33 & 1.00 & 3.47 & 2.72 & 29.80 & 17.67 & 45.84 & 52.32 \\
\hline L92 & 4.33 & 1.67 & 3.26 & 2.58 & 41.54 & 28.57 & 42.69 & 48.01 \\
\hline L28 & 2.67 & 3.00 & 2.70 & 2.27 & 28.49 & 22.06 & 44.36 & 48.26 \\
\hline L12 & 3.67 & 2.33 & 2.89 & 2.28 & 30.43 & 17.45 & 43.73 & 48.31 \\
\hline L93 & 2.33 & 2.00 & 2.49 & 2.06 & 33.00 & 24.55 & 45.63 & 47.23 \\
\hline L110 & 3.33 & 2.67 & 2.89 & 2.31 & 35.85 & 25.17 & 46.72 & 47.59 \\
\hline LSD $5 \%$ & 0.24 & 0.23 & 0.06 & 0.06 & 1.20 & 1.40 & 0.42 & 0.43 \\
\hline LSD $1 \%$ & 0.33 & 0.31 & 0.08 & 0.08 & 1.60 & 1.87 & 0.56 & 0.57 \\
\hline $\mathrm{L} 95 \times \mathrm{L} 92$ & 5.33 & 3.67 & 4.72 & 3.10 & 34.04 & 19.00 & 44.15 & 55.50 \\
\hline $\mathrm{L} 95 \times \mathrm{L} 28$ & 3.33 & 3.00 & 3.40 & 2.55 & 36.68 & 28.25 & 43.99 & 48.48 \\
\hline $\mathrm{L} 95 \times \mathrm{L} 12$ & 5.67 & 4.67 & 4.57 & 3.80 & 35.00 & 25.82 & 47.61 & 51.65 \\
\hline $\mathrm{L} 95 \times \mathrm{L} 93$ & 4.33 & 3.33 & 3.64 & 2.92 & 32.72 & 27.22 & 45.82 & 50.83 \\
\hline $\mathrm{L} 95 \times \mathrm{L} 110$ & 7.00 & 5.33 & 4.54 & 3.67 & 38.00 & 27.48 & 48.36 & 52.90 \\
\hline $\mathrm{L} 92 \times \mathrm{L} 28$ & 5.00 & 3.67 & 4.61 & 3.60 & 38.13 & 28.56 & 44.92 & 51.77 \\
\hline $\mathrm{L} 92 \times \mathrm{L} 12$ & 5.67 & 4.00 & 3.80 & 2.85 & 39.98 & 32.02 & 48.79 & 52.90 \\
\hline L92 × L93 & 4.33 & 3.00 & 3.60 & 2.87 & 36.75 & 33.50 & 47.22 & 51.77 \\
\hline $\mathrm{L} 92 \times \mathrm{L} 110$ & 5.33 & 3.67 & 3.71 & 3.20 & 51.27 & 37.53 & 46.73 & 51.77 \\
\hline $\mathrm{L} 28 \times \mathrm{L} 12$ & 4.67 & 3.33 & 3.38 & 2.71 & 45.16 & 34.69 & 43.03 & 48.65 \\
\hline $\mathrm{L} 28 \times \mathrm{L} 93$ & 5.33 & 3.67 & 2.52 & 2.60 & 42.12 & 33.91 & 46.02 & 50.28 \\
\hline $\mathrm{L} 28 \times \mathrm{L} 110$ & 4.67 & 3.33 & 3.50 & 2.73 & 38.85 & 31.37 & 47.19 & 51.43 \\
\hline $\mathrm{L} 12 \times \mathrm{L} 93$ & 5.33 & 3.33 & 3.50 & 2.70 & 37.39 & 27.39 & 44.23 & 47.94 \\
\hline $\mathrm{L} 12 \times \mathrm{L} 110$ & 6.00 & 4.67 & 3.46 & 2.81 & 35.58 & 26.91 & 44.09 & 47.66 \\
\hline $\mathrm{L} 93 \times \mathrm{L} 110$ & 5.67 & 3.67 & 3.39 & 2.89 & 38.48 & 28.24 & 47.14 & 51.87 \\
\hline LSD 5\% & 0.39 & 0.37 & 0.10 & 0.10 & 1.89 & 2.21 & 0.66 & 0.68 \\
\hline LSD $1 \%$ & 0.52 & 0.49 & 0.13 & 0.13 & 2.53 & 2.95 & 0.88 & 0.91 \\
\hline
\end{tabular}

\section{Combining ability}

Types of combining ability either general (GCA) or specific (SCA) and their respective symbol in Jones (1965) as additive gene action (a) and non-additive (b) were highly significant in respect to all studied traits under both contrasting irrigation regimes (Table 6) and their combined analysis (Table 7). This indicated that both types of genes either additive or non-additive played a major role in the inheritance of all studied traits. Whereas, the additive gene action was preponderant in the gene expression of most studied traits under both irrigation regimes and their combined analysis as verified by baker ratio and $(\mathrm{a} / \mathrm{b})$ ratio of Jones method. Moreover, interaction of irrigation with both types of combining ability was highly significant for all studied traits, indicating that types of gene action had highly significant response to environmental variability. In the approach used by Jones (1965), directional dominance $\left(b_{1}\right)$ was significant under both irrigation regimes and their combined analysis, indicating that the existence of directional dominance with the preponderance of additive gene action (Tables 6 and 7). The significance of distribution of dominant and recessive alleles in parents $\left(b_{2}\right)$ for all studied traits was observed under both irrigation regimes and their combined analysis. This showed the presence of asymmetrical distribution of dominant and recessive genes in parents. Specific gene interactions or epistasis was detected for all studied traits under both irrigation regimes and their combined analysis, as revealed by the significance of dominance deviation unique to $\mathrm{F}_{1} \mathrm{~S}$ $\left(b_{3}\right)$. Similar results were reported by Fahmy et al. (2015), Abd EL-Satar et al. (2016) and Jeeva et al. (2020), they stated that additive gene action had greater contribution in the inheritance of seed yield and its contributing traits.

\section{Combining ability effects:}

\section{General combining ability effects}

General combining ability (GCA) effects were estimated for the parental sesame genotypes and specific combining ability (SCA) effects for $\mathrm{F}_{1}$ crosses are presented in Table 8 . The best combiners with highly significant and negative estimates of GCA effects for earliness in flowering were exhibited by L110 and L92 under NI and L110 and L12 under WSC. Moreover, L93 (-5.82 and -4.00$)$ and L12 (-3.78 and -4.21) in both NI and WSC proved to be good combiners, respectively, again as desirable direction, with highly significant and negative GCA effects towards dwarfness. These parents were considered as good general combiners for these traits and could be used in breeding programs to develop earliness in flowering and short stature varieties. 
Table 6. Half diallel's analyses with Griffing method 2 model 1 (1956) and Jones (1965) for all studied traits across normal irrigation (N) and water stress conditions (S) in 2019 season

\begin{tabular}{|c|c|c|c|c|c|c|c|c|c|c|}
\hline \multicolumn{2}{|l|}{ SOV } & \multirow{2}{*}{ df } & \multicolumn{2}{|c|}{ Days to $50 \%$ flowering } & \multicolumn{2}{|c|}{ Plant height } & \multicolumn{2}{|c|}{ Fruiting zone length } & \multicolumn{2}{|c|}{ Capsules length } \\
\hline Griffing & Jones & & $\mathbf{N}$ & $\mathbf{S}$ & $\mathbf{N}$ & $\mathbf{S}$ & $\mathbf{N}$ & $\mathbf{S}$ & $\mathbf{N}$ & $\mathbf{S}$ \\
\hline GCA & $\mathrm{a}$ & 5 & $27.02 * *$ & $15.74 * *$ & $301.41 * *$ & $195.81 * *$ & $267.95 * *$ & $107.65^{* *}$ & $0.32 * *$ & $0.10^{* *}$ \\
\hline b1 & & 1 & $65.19 * *$ & $33.60 * *$ & $585.56^{* *}$ & $363.62 * *$ & $1407.49 * *$ & $540.00 * *$ & $1.08 * *$ & $0.65^{* *}$ \\
\hline b2 & & 5 & $19.82 * *$ & $2.77 * *$ & $296.50 * *$ & $164.43^{* *}$ & $63.32 * *$ & $28.02 * *$ & $0.05^{* *}$ & $0.05^{* *}$ \\
\hline b3 & & 9 & $15.41 * *$ & $17.32 * *$ & $104.63 * *$ & $71.13 * *$ & $48.72 * *$ & $33.03 * *$ & $0.09 * *$ & $0.05^{* *}$ \\
\hline SCA & $\mathrm{b}$ & 15 & $20.20 * *$ & $13.56^{* *}$ & $200.65 * *$ & $121.73^{* *}$ & $144.17 * *$ & $65.16^{* *}$ & $0.14 * *$ & $0.09 * *$ \\
\hline Total & & 20 & $21.90 * *$ & $14.10^{* *}$ & $225.84 * *$ & $140.25^{* *}$ & $175.12 * *$ & $75.78 * *$ & $0.19 * *$ & $0.09^{* *}$ \\
\hline Error & & 40 & 0.17 & 0.25 & 1.71 & 1.48 & 0.91 & 1.28 & 0.01 & 0.004 \\
\hline Baker ratio & & & 0.73 & 0.70 & 0.75 & 0.76 & 0.79 & 0.77 & 0.82 & 0.70 \\
\hline \multicolumn{2}{|l|}{ SOV } & df & \multicolumn{2}{|c|}{$\begin{array}{c}\text { Number of branches } \\
\text { per plant }\end{array}$} & \multicolumn{2}{|c|}{ 1000-seed weight } & \multicolumn{2}{|c|}{ Seed weight per plant } & \multicolumn{2}{|c|}{ Seed oil content } \\
\hline Griffing & Jones & & $\mathbf{N}$ & $\mathrm{S}$ & $\mathbf{N}$ & 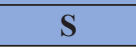 & $\mathbf{N}$ & $S$ & $\mathbf{N}$ & $\mathbf{S}$ \\
\hline GCA & $\mathrm{a}$ & 5 & $1.39^{* *}$ & $0.49 * *$ & $0.70 * *$ & $0.20 * *$ & $34.76^{* *}$ & $35.44 * *$ & $3.00 * *$ & $7.36^{* *}$ \\
\hline b1 & & 1 & $21.38^{* *}$ & $11.59 * *$ & $2.79 * *$ & $1.71 * *$ & $129.24 * *$ & $203.01 * *$ & $5.42 * *$ & $24.82 * *$ \\
\hline b2 & & 5 & $0.69^{*}$ & $0.70 * *$ & $0.11 * *$ & $0.02 * *$ & $13.99 * *$ & $9.45^{*}$ & $1.44 * *$ & $3.99 * *$ \\
\hline b3 & & 9 & $0.60^{*}$ & $0.30^{*}$ & $0.19 * *$ & $0.15^{* *}$ & $19.87 * *$ & $17.53 * *$ & $3.77 * *$ & $2.66^{* *}$ \\
\hline SCA & $\mathrm{b}$ & 15 & $2.02 * *$ & $1.19^{* *}$ & $0.34 * *$ & $0.21 * *$ & $25.20 * *$ & $27.20 * *$ & $3.11 * *$ & $4.58^{* *}$ \\
\hline Total & & 20 & $1.86^{* *}$ & $1.01 * *$ & $0.43 * *$ & $0.21 * *$ & $27.59 * *$ & $29.26 * *$ & $3.08 * *$ & $5.28 * *$ \\
\hline Error & & 40 & 0.11 & 0.10 & 0.01 & 0.01 & 2.63 & 3.58 & 0.32 & 0.34 \\
\hline Baker ratio & & & 0.58 & 0.45 & 0.81 & 0.65 & 0.73 & 0.72 & 0.66 & 0.76 \\
\hline
\end{tabular}

Note: "GCA and SCA of Griffing (1956)" and "a=additive effects, b=total non-additive (dominance) effects, b1=mean deviation of F1's from their mid-parents, $b 2=$ test if there is equal or unequal distribution among parents and $b 3=$ detect existence of unique dominance of each F1, i.e., presence of considerable amount of heterotic effect specific to some crosses of Jones (1965) modification";*, ** significant at 0.05 and 0.01 level of probability, respectively

Table 7. Half diallel's analyses with Griffing method 2 model 1 (1956) and Jones (1965) for all studied traits across irrigation regimes in 2019 season

\begin{tabular}{|c|c|c|c|c|c|c|c|c|c|c|}
\hline \multicolumn{2}{|l|}{ Source } & \multirow{2}{*}{ d.f } & \multirow{2}{*}{$\begin{array}{l}\text { Days to } 50 \% \\
\text { flowering }\end{array}$} & \multirow{2}{*}{$\begin{array}{l}\text { Plant } \\
\text { height }\end{array}$} & \multirow{2}{*}{$\begin{array}{l}\text { Fruiting } \\
\text { zone } \\
\text { length }\end{array}$} & \multirow{2}{*}{$\begin{array}{c}\text { Capsules } \\
\text { length }\end{array}$} & \multirow{2}{*}{$\begin{array}{l}\text { Number of } \\
\text { branches } \\
\text { per plant }\end{array}$} & \multirow{2}{*}{$\begin{array}{c}\text { 1000-seed } \\
\text { weight }\end{array}$} & \multirow{2}{*}{$\begin{array}{c}\text { Seed weight } \\
\text { per plant }\end{array}$} & \multirow{2}{*}{$\begin{array}{l}\text { Seed oil } \\
\text { content }\end{array}$} \\
\hline Griffing & Jones & & & & & & & & & \\
\hline GCA & $\mathrm{a}$ & 4 & $41.60 * *$ & $488.90 * *$ & $354.88^{* *}$ & $0.39 * *$ & $1.41 * *$ & $0.82 * *$ & $64.87 * *$ & $6.28 * *$ \\
\hline b1 & & 1 & $96.19 * *$ & $936.02 * *$ & $1845.56^{* *}$ & $1.70 * *$ & $32.22 * *$ & $4.44 * *$ & $328.11 * *$ & $26.72 * *$ \\
\hline b2 & & 4 & $14.15^{* *}$ & $446.52 * *$ & $77.10^{* *}$ & $0.08 * *$ & $1.18^{* *}$ & $0.10^{* *}$ & $22.13 * *$ & $4.72 * *$ \\
\hline b3 & & 5 & $24.43 * *$ & $172.61^{* *}$ & $75.04 * *$ & $0.13 * *$ & $0.84 * *$ & $0.30 * *$ & $32.67 * *$ & $4.94 * *$ \\
\hline SCA & $\mathrm{b}$ & 10 & $25.79 * *$ & $314.81^{* *}$ & $193.76^{* *}$ & $0.22 * *$ & $3.04 * *$ & $0.51 * *$ & $48.85^{* *}$ & $6.32 * *$ \\
\hline$a * I$ & & 4 & $1.16^{* *}$ & $8.32 * *$ & $20.72 * *$ & $0.03 * *$ & $0.47 * *$ & $0.08 * *$ & 5.33 & $4.08 * *$ \\
\hline $\mathrm{b} 1 * \mathrm{I}$ & & 1 & $2.59 * *$ & $13.16^{* *}$ & $101.94 * *$ & $0.03^{*}$ & $0.74 * *$ & $0.07 * *$ & 4.15 & $3.52 * *$ \\
\hline $\mathrm{b} 2 * \mathrm{I}$ & & 4 & $8.44 * *$ & $14.41 * *$ & $14.24 * *$ & 0.01 & 0.21 & $0.03 * *$ & 1.31 & 0.71 \\
\hline $\mathrm{b} 3 * \mathrm{I}$ & & 5 & $8.30 * *$ & 3.15 & $6.71^{* *}$ & $0.01 *$ & 0.07 & $0.04 * *$ & 4.72 & $1.49 * *$ \\
\hline $\mathrm{SCA} \times \mathrm{I}$ & $\mathrm{b} \times \mathrm{I}$ & 10 & $7.97 * *$ & $7.57 * *$ & $15.57 * *$ & $0.01 * *$ & 0.16 & $0.04 * *$ & 3.54 & $1.37 * *$ \\
\hline Error & & 80 & 0.21 & 1.60 & 1.09 & 0.01 & 0.11 & 0.01 & 3.11 & 0.33 \\
\hline
\end{tabular}

Note: I=irrigation regimes; "GCA and SCA of Griffing (1956)" and " $\mathrm{a}=$ additive effects, $\mathrm{b}=$ total non-additive (dominance) effects, b1=mean deviation of F1's from their mid-parents, b2=test if there is equal or unequal distribution among parents and b3=detect existence of unique dominance of each F1, i.e., presence of considerable amount of heterotic effect specific to some crosses of Jones (1965) modification"; *, ** significant at 0.05 and 0.01 level of probability, respectively

The positive direction of GCA effects for seed weight per plant and its components is desirable. The best GCA effects was detected in L95 and L92 under NI and L95 and L28 under WSC for fruiting zone length, L95 and L93 under both irrigation regimes for capsules length, L110 and L12 under both irrigation regimes for branches number per plant, L95 and L92 under both irrigation regimes for 1000seed weight, L92 and L110 under both irrigation regimes for seed weight per plant and L110 and L93 under NI and L95 and L92 under WSC for seed oil content. This result corroborates with the findings of Fahmy et al. (2015), Abd EL-Satar et al. (2016), Ismail et al. (2020) and Jeeva et al.
(2020), they created GCA effects in the desired direction for seed yield and yield components.

\section{Specific Combining Ability Effects}

The created combinations showed a large variation in the SCA effects (Tables 9a, 9b) either in the desired or undesired direction under normal irrigation and water stress conditions. Accordingly, the possibility of selection for the desired effects, where a negative effect on days to $50 \%$ flowering and plant height is desirable, but a positive effect on seed yield and its components is desirable. 
Table 8. General combining ability effects of six parental sesame genotypes for all studied traits under normal irrigation $(\mathrm{N})$ and water stress conditions (S) in 2019 season

\begin{tabular}{|c|c|c|c|c|c|c|c|c|}
\hline \multirow[t]{2}{*}{ Parents } & \multicolumn{2}{|c|}{ Days to $50 \%$ flowering } & \multicolumn{2}{|c|}{ Plant height } & \multicolumn{2}{|c|}{ Fruiting zone length } & \multicolumn{2}{|c|}{ Capsules length } \\
\hline & $\mathbf{N}$ & $\mathbf{S}$ & $\mathbf{N}$ & $\mathbf{S}$ & $\mathbf{N}$ & $\mathbf{S}$ & $\mathbf{N}$ & $\mathbf{S}$ \\
\hline L95 & $1.79^{* *}$ & $1.19^{* *}$ & $11.51 * *$ & $9.21 * *$ & $10.22 * *$ & $6.32 * *$ & $0.33 * *$ & $0.20 * *$ \\
\hline L92 & $-0.96^{* *}$ & -0.26 & $-2.03 * *$ & -0.79 & $1.28^{* *}$ & 0.01 & 0.02 & 0.01 \\
\hline L28 & $2.38^{* *}$ & $1.94 * *$ & $1.39 * *$ & $1.17 * *$ & 0.11 & $1.24 * *$ & $-0.26 * *$ & $-0.10 * *$ \\
\hline L12 & -0.13 & $-0.43 *$ & $-3.78 * *$ & $-4.21^{* *}$ & $-0.93 * *$ & $-0.78^{*}$ & 0.01 & -0.01 \\
\hline L93 & $-0.46^{* *}$ & $-0.39 *$ & $-5.82 * *$ & $-4.00^{* *}$ & $-4.05 * *$ & $-2.34 * *$ & 0.04 & 0.02 \\
\hline L110 & $-2.62 * *$ & $-2.06^{* *}$ & $-1.28 * *$ & $-1.37^{* *}$ & $-6.64 * *$ & $-4.45 * *$ & $-0.14^{* *}$ & $-0.12 * *$ \\
\hline LSD gi $5 \%$ & 0.27 & 0.33 & 0.85 & 0.79 & 0.62 & 0.74 & 0.05 & 0.04 \\
\hline LSD gi $1 \%$ & 0.36 & 0.44 & 1.14 & 1.06 & 0.83 & 0.99 & 0.07 & 0.06 \\
\hline LSD gi-gj $5 \%$ & 0.73 & 0.90 & 2.34 & 2.18 & 1.71 & 2.03 & 0.15 & 0.12 \\
\hline LSD gi-gj $1 \%$ & 0.98 & 1.21 & 3.14 & 2.92 & 2.28 & 2.72 & 0.20 & 0.16 \\
\hline \multirow[t]{2}{*}{ Parents } & \multicolumn{2}{|c|}{$\begin{array}{c}\text { Number of branches per } \\
\text { plant }\end{array}$} & \multicolumn{2}{|c|}{ 1000-seed weight } & \multicolumn{2}{|c|}{ Seed weight per plant } & \multicolumn{2}{|c|}{ Seed oil content } \\
\hline & $\mathbf{N}$ & $\mathrm{S}$ & $\mathbf{N}$ & S & $\mathbf{N}$ & S & $\mathbf{N}$ & S \\
\hline L95 & $-0.43^{* *}$ & -0.13 & $0.39 * *$ & $0.22 * *$ & $-2.96 * *$ & $-3.67 * *$ & 0.27 & $1.45^{* *}$ \\
\hline L92 & $0.32 * *$ & $-0.21 *$ & $0.29 * *$ & $0.13 * *$ & $2.94 * *$ & $1.91 * *$ & -0.28 & $0.92 * *$ \\
\hline L28 & $-0.43^{* *}$ & 0.00 & $-0.23 * *$ & $-0.13^{* *}$ & -0.23 & 1.06 & $-0.69 * *$ & $-0.65 * *$ \\
\hline L12 & $0.36^{* *}$ & $0.21^{*}$ & -0.02 & -0.04 & -0.72 & $-1.34 *$ & $-0.53 * *$ & $-0.87 * *$ \\
\hline L93 & $-0.26^{*}$ & $-0.25 *$ & $-0.38 * *$ & $-0.21 * *$ & -0.79 & 0.86 & 0.28 & $-0.65 * *$ \\
\hline L110 & $0.44 * *$ & $0.38 * *$ & -0.04 & 0.02 & $1.76^{* *}$ & 1.18 & $0.94 * *$ & -0.20 \\
\hline LSD gi $5 \%$ & 0.22 & 0.21 & 0.06 & 0.06 & 1.06 & 1.23 & 0.37 & 0.38 \\
\hline LSD gi $1 \%$ & 0.29 & 0.27 & 0.08 & 0.08 & 1.42 & 1.65 & 0.49 & 0.51 \\
\hline LSD gi-gj $5 \%$ & 0.60 & 0.56 & 0.16 & 0.16 & 2.91 & 3.39 & 1.01 & 1.04 \\
\hline LSD gi-gj $1 \%$ & 0.80 & 0.76 & 0.21 & 0.22 & 3.89 & 4.54 & 1.36 & 1.39 \\
\hline
\end{tabular}

Note: $*$, ** refers to significant at $5 \%$ and highly significant at $1 \%$, respectively

Table 9a. Specific combining ability effects of $15 \mathrm{~F}_{1}$ cross combinations for days to $50 \%$ flowering, plant height, fruiting zone length and capsules length under normal irrigation (N) and water stress conditions (S) in 2019 season.

\begin{tabular}{|c|c|c|c|c|c|c|c|c|}
\hline \multirow{2}{*}{ Crosses } & \multicolumn{2}{|c|}{ Days to $50 \%$ flowering } & \multicolumn{2}{|c|}{ Plant height } & \multicolumn{2}{|c|}{ Fruiting zone length } & \multicolumn{2}{|c|}{ Capsules length } \\
\hline & $\mathbf{N}$ & $\mathbf{S}$ & $\mathbf{N}$ & $\mathbf{S}$ & $\mathbf{N}$ & $\mathbf{S}$ & $\mathbf{N}$ & $\mathbf{S}$ \\
\hline $\mathrm{L} 95 \times \mathrm{L} 92$ & -0.55 & $-4.04 * *$ & $-3.14 * *$ & $-3.23 * *$ & $14.01 * *$ & $13.43 * *$ & 0.00 & $-0.17 * *$ \\
\hline $\mathrm{L} 95 \times \mathrm{L} 28$ & $-5.21 * *$ & $-3.25 * *$ & $11.78 * *$ & $7.82 * *$ & $15.18 * *$ & $7.00 * *$ & $0.68 * *$ & $0.51 * *$ \\
\hline $\mathrm{L} 95 \times \mathrm{L} 12$ & $5.62 * *$ & $6.13^{* *}$ & $-17.72 * *$ & $-12.48 * *$ & $9.22 * *$ & $6.70 * *$ & 0.12 & 0.04 \\
\hline $\mathrm{L} 95 \times \mathrm{L} 93$ & $0.95 * *$ & $1.75^{* *}$ & $6.99 * *$ & $6.98 * *$ & -0.99 & $-3.70 * *$ & $0.45 * *$ & $0.53 * *$ \\
\hline $\mathrm{L} 95 \times \mathrm{L} 110$ & $-2.88 * *$ & $-2.92 * *$ & $-17.89 * *$ & $-15.98 * *$ & $3.26 * *$ & $5.72 * *$ & 0.04 & -0.01 \\
\hline $\mathrm{L} 92 \times \mathrm{L} 28$ & 0.54 & $0.88^{*}$ & -1.35 & -0.52 & $4.45 * *$ & $7.92 * *$ & 0.03 & 0.01 \\
\hline $\mathrm{L} 92 \times \mathrm{L} 12$ & $4.04 * *$ & $1.92 * *$ & $-4.51 * *$ & $-3.48 * *$ & $1.83^{*}$ & -0.82 & $0.30 * *$ & $0.18^{* *}$ \\
\hline L92 × L93 & $-2.96 * *$ & $-3.13 * *$ & $10.86^{* *}$ & $6.32 * *$ & $-4.05 * *$ & $-4.29 * *$ & $0.13 *$ & $0.13 * *$ \\
\hline $\mathrm{L} 92 \times \mathrm{L} 110$ & $-6.13 * *$ & $-3.13 * *$ & $-9.35 * *$ & $-9.98 * *$ & $-2.80 * *$ & $-2.23 *$ & -0.02 & $0.12 *$ \\
\hline $\mathrm{L} 28 \times \mathrm{L} 12$ & $1.37 * *$ & $-5.29 * *$ & $2.07 *$ & $4.57 * *$ & $5.66^{* *}$ & 1.32 & 0.08 & $0.15^{* *}$ \\
\hline L28 × L93 & $1.37 * *$ & $-1.33 * *$ & $-6.22 * *$ & $-6.98 * *$ & $10.45 * *$ & $2.13 *$ & 0.04 & $0.13 *$ \\
\hline $\mathrm{L} 28 \times \mathrm{L} 110$ & $-3.13 * *$ & $5.67 * *$ & $13.24 * *$ & $11.40 * *$ & $3.03 * *$ & 0.78 & $-0.17 * *$ & 0.02 \\
\hline $\mathrm{L} 12 \times \mathrm{L} 93$ & $-4.13 * *$ & $-0.96^{*}$ & -1.05 & -0.60 & $2.16^{* *}$ & $3.67 * *$ & $-0.32 * *$ & $-0.21 * *$ \\
\hline $\mathrm{L} 12 \times \mathrm{L} 110$ & $-6.63 * *$ & $-2.63 * *$ & $-17.26^{* *}$ & $-11.23 * *$ & -0.26 & 0.83 & $0.33 * *$ & 0.03 \\
\hline $\mathrm{L} 93 \times \mathrm{L} 110$ & $1.04 * *$ & $-1.67 * *$ & $-16.55^{* *}$ & $-12.10^{* *}$ & $16.53 * *$ & $9.64 * *$ & $0.46^{* *}$ & $0.20 * *$ \\
\hline LSD Sij 5\% & 0.60 & 0.75 & 1.93 & 1.80 & 1.41 & 1.68 & 0.12 & 0.10 \\
\hline LSD Sij 1\% & 0.81 & 1.00 & 2.59 & 2.41 & 1.88 & 2.24 & 0.17 & 0.13 \\
\hline LSD sij-sik 5\% & 1.09 & 1.35 & 3.50 & 3.26 & 2.55 & 3.03 & 0.22 & 0.18 \\
\hline LSD sij-sik 1\% & 1.46 & 1.80 & 4.68 & 4.36 & 3.41 & 4.05 & 0.30 & 0.24 \\
\hline LSD sij-skl 5\% & 1.01 & 1.25 & 3.24 & 3.02 & 2.36 & 2.80 & 0.21 & 0.17 \\
\hline LSD sij-skl 1\% & 1.35 & 1.67 & 4.33 & 4.04 & 3.15 & 3.75 & 0.28 & 0.22 \\
\hline
\end{tabular}

Note: $*, * *$ refers to significant at $5 \%$ and highly significant at $1 \%$, respectively

High and negative SCA effects was observed in L12 $\times \mathrm{L} 110$, and L92 $\times$ L110 under NI and L28 $\times$ L12 and L95 $\times$ L92 under WSC for earliness in flowering and L95 $\times$ L110 and L95 $\times$ L12 under both irrigation regimes for plant height. Conversely, high and positive SCA effects were detected in L93 $\times \mathrm{L} 110$ and $\mathrm{L} 95 \times \mathrm{L} 28$ under NI and L95 $\times$ L92 and L93 $\times$ L110 under WSC for fruiting zone length, the cross combinations L95 $\times$ L28 and L93 $\times$ L110 
Table 9b. Specific combining ability effects of $15 \mathrm{~F}_{1}$ cross combinations for number of branches per plant, 1000-seed weight, seed weight per plant and seed oil content under normal irrigation $(\mathrm{N})$ and water stress conditions $(\mathrm{S})$ in 2019 season

\begin{tabular}{|c|c|c|c|c|c|c|c|c|}
\hline \multirow{2}{*}{ Crosses } & \multicolumn{2}{|c|}{$\begin{array}{c}\text { Number of branches } \\
\text { per plant }\end{array}$} & \multicolumn{2}{|c|}{1000 -seed weight } & \multicolumn{2}{|c|}{ Seed weight per plant } & \multicolumn{2}{|c|}{ Seed oil content } \\
\hline & $\mathbf{N}$ & $\mathbf{S}$ & $\mathbf{N}$ & S & $\mathbf{N}$ & S & $\mathbf{N}$ & $\mathbf{S}$ \\
\hline $\mathrm{L} 95 \times \mathrm{L} 92$ & $0.90 * *$ & $0.71 * *$ & $0.52 * *$ & -0.07 & $-3.04 *$ & $-6.74 * *$ & $-1.48 * *$ & $2.79 * *$ \\
\hline $\mathrm{L} 95 \times \mathrm{L} 28$ & -0.35 & -0.16 & $-0.28 * *$ & $-0.36^{* *}$ & $2.76^{*}$ & $3.37 *$ & $-1.22 * *$ & $-2.66 * *$ \\
\hline $\mathrm{L} 95 \times \mathrm{L} 12$ & $1.20^{* *}$ & $1.30^{* *}$ & $0.67 * *$ & $0.80^{* *}$ & 1.58 & $3.34 *$ & $2.23 * *$ & 0.73 \\
\hline $\mathrm{L} 95 \times \mathrm{L} 93$ & 0.49 & 0.42 & 0.10 & 0.09 & -0.64 & 2.53 & -0.37 & -0.31 \\
\hline $\mathrm{L} 95 \times \mathrm{L} 110$ & $2.45 * *$ & $1.80 * *$ & $0.66^{* *}$ & $0.61 * *$ & 2.09 & 2.47 & $1.52 * *$ & $1.30 * *$ \\
\hline $\mathrm{L} 92 \times \mathrm{L} 28$ & $0.57^{*}$ & $0.59^{*}$ & $1.03 * *$ & $0.77^{* *}$ & -1.69 & -1.90 & 0.26 & $1.16^{* *}$ \\
\hline $\mathrm{L} 92 \times \mathrm{L} 12$ & 0.45 & $0.71 * *$ & 0.01 & -0.06 & 0.66 & $3.96^{* *}$ & $3.96 * *$ & $2.51 * *$ \\
\hline L92 $\times$ L93 & -0.26 & 0.17 & $0.17 *$ & 0.13 & $-2.51^{*}$ & $3.24 *$ & $1.59 * *$ & $1.16^{* *}$ \\
\hline $\mathrm{L} 92 \times \mathrm{L} 110$ & 0.03 & 0.21 & -0.06 & $0.23 * *$ & $9.46^{* *}$ & $6.95 * *$ & 0.43 & 0.71 \\
\hline $\mathrm{L} 28 \times \mathrm{L} 12$ & 0.20 & -0.16 & 0.11 & 0.06 & $9.01 * *$ & $7.48 * *$ & $-1.38^{* *}$ & -0.17 \\
\hline $\mathrm{L} 28 \times \mathrm{L} 93$ & $1.49 * *$ & $0.63 * *$ & $-0.39 * *$ & 0.11 & $6.03 * *$ & $4.50 * *$ & 0.80 & $1.25^{* *}$ \\
\hline $\mathrm{L} 28 \times \mathrm{L} 110$ & 0.11 & -0.33 & $0.24 * *$ & 0.01 & 0.20 & 1.65 & $1.31 * *$ & $1.94 * *$ \\
\hline $\mathrm{L} 12 \times \mathrm{L} 93$ & $0.70 * *$ & 0.09 & $0.38 * *$ & 0.12 & 1.79 & 0.38 & $-1.16^{* *}$ & $-0.88^{*}$ \\
\hline $\mathrm{L} 12 \times \mathrm{L} 110$ & $0.65^{*}$ & $0.80^{* *}$ & -0.01 & 0.01 & $-2.57^{*}$ & -0.42 & $-1.96^{* *}$ & $-1.61 * *$ \\
\hline $\mathrm{L} 93 \times \mathrm{L} 110$ & $0.95 * *$ & $0.26^{*}$ & $0.28 * *$ & $0.25^{* *}$ & $0.40 * *$ & -1.29 & $0.29 * *$ & $2.38 * *$ \\
\hline LSD Sij $5 \%$ & 0.49 & 0.47 & 0.13 & 0.13 & 2.40 & 2.80 & 0.84 & 0.86 \\
\hline LSD Sij $1 \%$ & 0.66 & 0.62 & 0.18 & 0.18 & 3.21 & 3.74 & 1.12 & 1.15 \\
\hline LSD sij-sik 5\% & 0.89 & 0.84 & 0.24 & 0.24 & 4.34 & 5.06 & 1.51 & 1.55 \\
\hline LSD sij-sik 1\% & 1.20 & 1.13 & 0.32 & 0.32 & 5.81 & 6.77 & 2.02 & 2.08 \\
\hline LSD sij-sk1 5\% & 0.83 & 0.78 & 0.22 & 0.22 & 4.02 & 4.68 & 1.40 & 1.44 \\
\hline LSD sij-skl 1\% & 1.11 & 1.04 & 0.29 & 0.30 & 5.38 & 6.27 & 1.87 & 1.92 \\
\hline
\end{tabular}

Note: $*, * *$ refers to significant at $5 \%$ and highly significant at $1 \%$, respectively

under NI and L95 $\times$ L93 and L95 $\times$ L28 under WSC had high and positive SCA effects for capsules length. In case of number of branches per plant, L95 $\times$ L110 and L28 $\times$ L93 under NI and L95 $\times$ L110 and L95 $\times$ L12 under WSC possessed high and positive SCA effects. The promising created combinations for 1000-seed weight was detected in L92 $\times$ L28 and L95 $\times$ L12 under NI and L95 $\times$ L12 and L92 $\times$ L28 under WSC.

The best SCA effects for seed weight per plant were observed in L92 $\times$ L110 and L28 $\times$ L12 under NI and L2 $8 \times$ L12 and L92 $\times$ L110 under WSC. The good cross combinations for seed oil content were shown by L92 $\times$ L12 and L95 $\times$ L12 under NI and L95 $\times$ L92 and L92 $\times$ L12 under WSC. This result corroborates with the findings of Fahmy et al. (2015), Abd EL-Satar et al. (2016), Ismail et al. (2020) and Jeeva et al. (2020), found that the genetic divergence among the parental genotypes had the largest effect on generated cross combinations, especially in estimation of SCA effects for seed yield and yield components.

\section{Heterotic effects}

Two types of heterosis i.e., mid parents heterosis (MPH) and better parents heterosis $(\mathrm{BPH})$ were estimated to identify the best cross combinations (Tables 10a, 10b, 10c, 10d).

Three types of cross combinations i.e. High $\times$ High, High $\times$ Low or Low $\times$ High and Low $\times$ Low were detected in created cross combinations, where High $(\mathrm{H})$ refer to significant GCA effects in the desired direction and Low (L) refers to non-significant GCA effects either in positive or negative direction. In case of High $\times$ High cross combinations, additive and additive $\times$ additive gene actions were governed in the inheritance of traits. Additive gene action predominated in the good combiner (High) and a complementary epistatic effect governed in the poor combiner (Low) as High $\times$ Low, so these two gene actions involved in gene expression of cross combination as described by Salimath and Bahl (1985). The cross combinations had Low $\times$ Low general combiners, indicating that non-additive gene action played a prominent role in the inheritance of seed yield traits as presented by Bhutia et al. (2014).

The desirable target was negative direction of for MPH and $\mathrm{BPH}$ for the earliness in flowering to produce high yield in a short period and short statured plant suitable for mechanical harvesting and resistant to lodging. Accordingly, the best cross combinations with $\mathrm{H} \times \mathrm{H}$ were detected in L92 $\times$ L110 over MPH and BPH under both irrigation regimes for earliness in flowering and L12 $\times$ L93 over MPH under both irrigation regimes for short statured plants and more crosses with $\mathrm{H} \times \mathrm{L}$ and $\mathrm{L} \times \mathrm{H}$ over $\mathrm{MPH}$ and $\mathrm{BPH}$ with negative potence ratio exceeding unity under both irrigation regimes.

Conversely, the cross combinations with positive direction are desirable for seed weight per plant and its 
Table 10a. Relative heterosis (MP) and heterbeltiosis (BP) as well as potence ratio (P) of $15 \mathrm{~F}_{1}$ cross combinations for days to flowering and plant height under normal irrigation (N) and water stress conditions (S) in 2019 season.

\begin{tabular}{|c|c|c|c|c|c|c|c|c|c|c|c|c|}
\hline \multirow{3}{*}{ Crosses } & \multicolumn{6}{|c|}{ Days to $50 \%$ flowering } & \multicolumn{6}{|c|}{ Plant height } \\
\hline & \multicolumn{3}{|c|}{$\mathbf{N}$} & \multicolumn{3}{|c|}{$\mathbf{S}$} & \multicolumn{3}{|c|}{$\mathbf{N}$} & \multicolumn{3}{|c|}{$\mathbf{S}$} \\
\hline & MP & $\mathbf{P}$ & BP & MP & $\mathbf{P}$ & BP & MP & $\mathbf{P}$ & $\mathbf{B P}$ & MP & $\mathbf{P}$ & $\mathbf{B P}$ \\
\hline L95 × L92 & $-3.66^{* *}$ & 1.17 & -0.54 & $-13.22 * *$ & 39.00 & $-12.93 * *$ & $-6.71 * *$ & 0.60 & $5.04 * *$ & $-8.68 * *$ & 0.88 & 1.26 \\
\hline $\mathrm{L} 95 \times \mathrm{L} 28$ & $-10.45^{* *}$ & 5.25 & $-8.63 * *$ & $-9.27 * *$ & 4.67 & $-7.43 * *$ & $8.01 * *$ & -0.58 & $25.20 * *$ & $6.82 * *$ & -0.47 & $25.00 * *$ \\
\hline $\mathrm{L} 95 \times \mathrm{L} 12$ & $8.18 * *$ & -2.07 & $12.64 * *$ & $11.27 * *$ & -2.67 & $16.18 * *$ & $-20.86 * *$ & 3.03 & $-15.01 * *$ & $-19.26 * *$ & 1.90 & $-10.16^{* *}$ \\
\hline L95 × L93 & -0.78 & 0.27 & $2.15^{* *}$ & -0.34 & 0.20 & 1.40 & 0.35 & -0.02 & $17.20 * *$ & 1.03 & -0.07 & $17.53 * *$ \\
\hline $\mathrm{L} 95 \times \mathrm{L} 110$ & $-12.02 * *$ & 15.67 & $-11.34 * *$ & $-10.00 * *$ & 1.75 & $-4.55^{* *}$ & $-21.79 * *$ & 5.97 & $-18.83 * *$ & $-24.05 * *$ & 5.56 & $-20.62 * *$ \\
\hline $\mathrm{L} 92 \times \mathrm{L} 28$ & $-3.08 * *$ & 0.60 & $2.16 * *$ & $-3.65 * *$ & 1.57 & -1.36 & 1.29 & -0.50 & $3.98 *$ & 0.83 & -0.17 & $5.90 * *$ \\
\hline $\mathrm{L} 92 \times \mathrm{L} 12$ & $4.63 * *$ & -5.67 & $5.49 * *$ & -0.35 & 0.09 & $3.68 * *$ & $-11.57 * *$ & 2.67 & $-7.56^{* *}$ & $-11.39 * *$ & 36.00 & $-11.11 * *$ \\
\hline $\mathrm{L} 92 \times \mathrm{L} 93$ & $-8.36^{* *}$ & 31.00 & $-8.11 * *$ & $-13.10 * *$ & 9.50 & $-11.89 * *$ & $5.85 * *$ & -1.80 & $9.41 * *$ & 1.97 & -0.46 & $6.53 * *$ \\
\hline $\mathrm{L} 92 \times \mathrm{L} 110$ & $-18.73 * *$ & 7.89 & $-16.76 * *$ & $-13.26 * *$ & 2.47 & $-8.33 * *$ & $-16.18 * *$ & 2.14 & $-9.32 * *$ & $-19.82 * *$ & 3.59 & $-15.14 * *$ \\
\hline $\mathrm{L} 28 \times \mathrm{L} 12$ & 0.26 & -0.04 & $6.59 * *$ & $-13.10 * *$ & 2.11 & $-7.35 * *$ & -1.98 & 0.29 & $5.31 * *$ & 2.82 & -0.63 & $7.64 * *$ \\
\hline $\mathrm{L} 28 \times \mathrm{L} 93$ & $-1.28 *$ & 0.26 & $3.76^{* *}$ & $-7.07 * *$ & 1.91 & $-3.50 * *$ & -2.27 & 3.40 & -1.61 & $-4.66^{* *}$ & 9.00 & $-4.17 *$ \\
\hline $\mathrm{L} 28 \times \mathrm{L} 110$ & $-13.28 * *$ & 4.82 & $-10.82 * *$ & $7.69 * *$ & -1.00 & $16.67 * *$ & $4.41 * *$ & -0.44 & $16.18 * *$ & $5.61 * *$ & -0.55 & $17.71 * *$ \\
\hline $\mathrm{L} 12 \times \mathrm{L} 93$ & $-8.15^{* *}$ & 7.50 & $-7.14 * *$ & $-5.38 * *$ & 2.14 & $-2.94 * *$ & $-9.07 * *$ & 1.20 & -1.61 & $-7.92 * *$ & 2.00 & $-4.12 *$ \\
\hline $\mathrm{L} 12 \times \mathrm{L} 110$ & $-17.55^{* *}$ & 5.50 & $-14.84 * *$ & $-8.96 * *$ & 6.00 & $-7.58 * *$ & $-26.03 * *$ & 8.03 & $-23.56 * *$ & $-23.77 * *$ & 4.08 & $-19.05 * *$ \\
\hline $\mathrm{L} 93 \times \mathrm{L} 110$ & $-6.84 * *$ & 3.25 & $-4.84 * *$ & $-9.09 * *$ & 2.27 & $-5.30 * *$ & $-21.58 * *$ & 2.00 & $-12.10 * *$ & $-21.55^{* *}$ & 2.21 & $-13.06^{* *}$ \\
\hline LSD $5 \%$ & 1.01 & & 1.17 & 1.25 & & 1.44 & 3.24 & & 3.74 & 3.02 & & 3.48 \\
\hline LSD $1 \%$ & 1.35 & & 1.56 & 1.67 & & 1.93 & 4.33 & & 5.00 & 4.04 & & 4.66 \\
\hline
\end{tabular}

Note: P refers to relative potency of the gene set; $*$, ** refers to significant at $5 \%$ and highly significant at $1 \%$, respectively

Table 10b. Relative heterosis (MP) and heterbeltiosis (BP) as well as potence ratio (P) of $15 \mathrm{~F}_{1}$ cross combinations for fruiting zone length and capsules length under normal irrigation $(\mathrm{N})$ and water stress conditions (S) in 2019 season.

\begin{tabular}{|c|c|c|c|c|c|c|c|c|c|c|c|c|}
\hline \multirow{3}{*}{ Crosses } & \multicolumn{6}{|c|}{ Fruiting zone length } & \multicolumn{6}{|c|}{ Capsules length } \\
\hline & \multicolumn{3}{|c|}{$\mathbf{N}$} & \multicolumn{3}{|c|}{$\mathbf{S}$} & \multicolumn{3}{|c|}{$\mathbf{N}$} & \multicolumn{3}{|c|}{$\mathbf{S}$} \\
\hline & MP & $\mathbf{P}$ & BP & MP & $\mathbf{P}$ & BP & MP & $\mathbf{P}$ & BP & MP & $\mathbf{P}$ & BP \\
\hline $\mathrm{L} 95 \times \mathrm{L} 92$ & $49.94 * *$ & 12.91 & $44.35 * *$ & $60.50 * *$ & 9.60 & $50.99 * *$ & $14.77 * *$ & 4.33 & $10.99 * *$ & $4.98 * *$ & 3.27 & $3.41 * *$ \\
\hline $\mathrm{L} 95 \times \mathrm{L} 28$ & $73.55^{* *}$ & 3.64 & $44.35 * *$ & $47.72 * *$ & 7.41 & $38.78 * *$ & $44.87 * *$ & 2.69 & $24.18^{* *}$ & $43.72 * *$ & 3.32 & $26.98 * *$ \\
\hline $\mathrm{L} 95 \times \mathrm{L} 12$ & $46.55^{* *}$ & 4.27 & $32.13 * *$ & $42.44 * *$ & 6.20 & $33.32 * *$ & $19.54 * *$ & 4.25 & $14.29 * *$ & $13.24 * *$ & 10.67 & $11.85 * *$ \\
\hline $\mathrm{L} 95 \times \mathrm{L} 93$ & $32.25 * *$ & 1.50 & $8.85 * *$ & $13.86^{* *}$ & 1.69 & $5.23 * *$ & $33.72 * *$ & 5.80 & $26.37 * *$ & $41.32 * *$ & 6.25 & $32.56^{* *}$ \\
\hline $\mathrm{L} 95 \times \mathrm{L} 110$ & $40.25^{* *}$ & 1.58 & $11.76^{* *}$ & $47.15^{* *}$ & 2.33 & $22.40 * *$ & $19.02 * *$ & 1.63 & $6.59 * *$ & $13.76^{* *}$ & 1.72 & $5.31 * *$ \\
\hline $\mathrm{L} 92 \times \mathrm{L} 28$ & $38.46^{* *}$ & 2.33 & $18.87 * *$ & $43.27 * *$ & 304.00 & $43.07 * *$ & $12.00 * *$ & 0.90 & $-1.18 * *$ & $13.25^{* *}$ & 1.13 & $1.40 * *$ \\
\hline $\mathrm{L} 92 \times \mathrm{L} 12$ & $19.87 * *$ & 2.81 & $11.95^{* *}$ & $15.02 * *$ & 27.79 & $14.40 * *$ & $19.05^{* *}$ & 16.00 & $17.65^{* *}$ & $12.18^{* *}$ & 43.50 & $11.87 * *$ \\
\hline $\mathrm{L} 92 \times \mathrm{L} 93$ & $11.85 * *$ & 0.67 & $-5.03 * *$ & $2.93 *$ & 1.54 & 1.00 & $15.66^{* *}$ & 6.50 & $12.94 * *$ & $17.49 * *$ & 3.43 & $11.80 * *$ \\
\hline $\mathrm{L} 92 \times \mathrm{L} 110$ & $12.64 * *$ & 0.58 & $-7.55^{* *}$ & $15.07 * *$ & 1.07 & 0.84 & $9.55 * *$ & 1.15 & $1.18^{* *}$ & $12.34 * *$ & 1.90 & $5.48 * *$ \\
\hline $\mathrm{L} 28 \times \mathrm{L} 12$ & $47.62 * *$ & 5.00 & $34.78 * *$ & $24.25^{* *}$ & 60.93 & $23.76 * *$ & $14.86^{* *}$ & 1.22 & $2.41 * *$ & $19.16^{* *}$ & 1.60 & $6.42 * *$ \\
\hline $\mathrm{L} 28 \times \mathrm{L} 93$ & $69.78 * *$ & 52.33 & $67.54 * *$ & $23.90 * *$ & 13.55 & $21.75 * *$ & $16.44 * *$ & 1.50 & $4.94 * *$ & $26.20 * *$ & 3.95 & $18.35 * *$ \\
\hline $\mathrm{L} 28 \times \mathrm{L} 110$ & $49.07 * *$ & 8.83 & $41.23 * *$ & $28.19 * *$ & 2.02 & $12.48 * *$ & $6.57 * *$ & 1.29 & $1.39 * *$ & $15.99 * *$ & 3.06 & $10.24 * *$ \\
\hline $\mathrm{L} 12 \times \mathrm{L} 93$ & $30.92 * *$ & 2.85 & $18.12 * *$ & $23.09 * *$ & 16.91 & $21.43 * *$ & 0.00 & 0.00 & $-1.20 * *$ & $1.40 * *$ & 0.26 & $-3.77 * *$ \\
\hline $\mathrm{L} 12 \times \mathrm{L} 110$ & $23.33 * *$ & 1.56 & $7.25 * *$ & $22.76^{* *}$ & 1.68 & $8.08 * *$ & $23.87 * *$ & 3.36 & $15.66^{* *}$ & $7.68 * *$ & 1.13 & $0.84 * *$ \\
\hline $\mathrm{L} 93 \times \mathrm{L} 110$ & $77.46^{* *}$ & 18.33 & $70.27 * *$ & $47.20 * *$ & 3.86 & $31.16^{* *}$ & $32.03 * *$ & 5.44 & $24.69 * *$ & $22.87 * *$ & 16.11 & $21.15^{* *}$ \\
\hline LSD 5\% & 2.36 & & 2.72 & 2.80 & & 3.24 & 0.21 & & 0.24 & 0.17 & & 0.19 \\
\hline LSD $1 \%$ & 3.15 & & 3.64 & 3.75 & & 4.33 & 0.28 & & 0.32 & 0.22 & & 0.26 \\
\hline
\end{tabular}

Note: P refers to relative potency of the gene set; $* * *$ refers to significant at $5 \%$ and highly significant at $1 \%$, respectively

components. Consequently, the best cross combinations with $\mathrm{H} \times \mathrm{H}$ were detected in L95 $\times$ L92 under normal irrigation (NI) and L95 $\times$ L28 under water stress conditions (WSC) over MPH and BPH for fruiting zone length, L95 $\times$ L93 over MPH and BPH under both irrigation regimes for capsules length, L12 $\times$ L110 over MPH and BPH under both irrigation regimes for number of branches per plant, L95 $\times$ L92 over MPH and BPH under both irrigation regimes for 1000-seed weight, L92 $\times$ L110 in MPH and $\mathrm{BPH}$ under both irrigation regimes for seed weight per plant, L93 $\times$ L110 over MPH and BPH under NI and L95 $\times$ L92 over MPH and BPH under WSC for seed oil content as well as more crosses with $\mathrm{H} \times \mathrm{L}$ and $\mathrm{L} \times \mathrm{H}$ over $\mathrm{MPH}$ and BPH with positive potence ratio exceeding unity under both irrigation regimes for all studied traits. Similar these findings were reported by Azeez and Morakinyo (2014), Ramesh et al. (2014), Fahmy et al. (2015), Abd EL-Satar et al. (2016), Ismail et al. (2020), and Jeeva et al. (2020), they found that high heterotic effects significantly affected by genetic variability of parental genotypes. 
Table 10c. Relative heterosis (MP) and heterbeltiosis (BP) as well as potence ratio (P) of $15 \mathrm{~F}_{1}$ cross combinations for number of branches per plant and 1000-seed weight under normal irrigation $(\mathrm{N})$ and water stress conditions $(\mathrm{S})$ in 2019 season

\begin{tabular}{|c|c|c|c|c|c|c|c|c|c|c|c|c|}
\hline \multirow{3}{*}{ Crosses } & \multicolumn{6}{|c|}{ Number of branches per plant } & \multicolumn{6}{|c|}{ 1000-seed weight } \\
\hline & \multicolumn{3}{|c|}{$\mathbf{N}$} & \multicolumn{3}{|c|}{$\mathbf{S}$} & \multicolumn{3}{|c|}{$\mathbf{N}$} & \multicolumn{3}{|c|}{$\mathbf{S}$} \\
\hline & MP & $\mathbf{P}$ & BP & MP & $\mathbf{P}$ & BP & MP & $\mathbf{P}$ & BP & MP & p & BP \\
\hline L95 × L92 & $88.24 * *$ & 1.67 & $23.08^{* *}$ & $175.00 * *$ & 7.00 & $120.00 * *$ & $40.17^{* *}$ & 13.30 & $36.06^{* *}$ & $17.13^{* *}$ & 6.48 & $14.11^{* *}$ \\
\hline $\mathrm{L} 95 \times \mathrm{L} 28$ & $66.67 * *$ & 2.00 & $25.00^{* *}$ & $50.00 * *$ & 1.00 & 0.00 & $10.44 * *$ & 0.84 & $-1.83^{* *}$ & $2.27 * *$ & 0.25 & $-6.13^{* *}$ \\
\hline $\mathrm{L} 95 \times \mathrm{L} 12$ & $126.67 * *$ & 2.71 & $54.55^{* *}$ & $180.00 * *$ & 4.50 & $100.00 * *$ & $43.61^{* *}$ & 4.84 & $31.73^{* *}$ & $52.23^{* *}$ & 5.98 & $40.00^{* *}$ \\
\hline $\mathrm{L} 95 \times \mathrm{L} 93$ & $136.36^{* *}$ & 5.00 & $85.71^{* *}$ & $122.22 * *$ & 3.67 & $66.67^{* *}$ & $22.17^{* *}$ & 1.35 & $4.90^{* *}$ & $22.21^{* *}$ & 1.61 & $7.36^{* *}$ \\
\hline $\mathrm{L} 95 \times \mathrm{L} 110$ & $200.00 * *$ & 4.67 & $110.00^{* *}$ & $190.91 * *$ & 4.20 & $100.00 * *$ & $42.92 * *$ & 4.70 & $30.96^{* *}$ & $46.06^{* *}$ & 5.74 & $35.21 * *$ \\
\hline L92 $\times$ L28 & $42.86^{* *}$ & 1.80 & $15.38^{* *}$ & $57.14^{* *}$ & 2.00 & $22.22 * *$ & $54.59^{* *}$ & 5.74 & $41.16^{* *}$ & $48.42 * *$ & 7.65 & $39.59^{* *}$ \\
\hline $\mathrm{L} 92 \times \mathrm{L} 12$ & $41.67 * *$ & 5.00 & $30.77 * *$ & $100.00^{* *}$ & 6.00 & $71.43^{* *}$ & $23.55^{* *}$ & 3.92 & $16.55^{* *}$ & $17.36^{* *}$ & 2.84 & $10.61^{* *}$ \\
\hline L92 × L93 & $30.00^{* *}$ & 1.00 & 0.00 & $63.64 * *$ & 7.00 & $50.00^{* *}$ & $25.22 * *$ & 1.87 & $10.32 * *$ & $24.03^{* *}$ & 2.14 & $11.51^{* *}$ \\
\hline $\mathrm{L} 92 \times \mathrm{L} 110$ & $39.13^{* *}$ & 3.00 & $23.08^{* *}$ & $69.23 * *$ & 3.00 & $37.50^{* *}$ & $20.65^{* *}$ & 3.37 & $13.69^{* *}$ & $31.02 * *$ & 5.76 & $24.32 * *$ \\
\hline $\mathrm{L} 28 \times \mathrm{L} 12$ & $47.37 * *$ & 3.00 & $27.27^{* *}$ & $25.00^{* *}$ & 2.00 & $11.11^{* *}$ & $21.05^{* *}$ & 5.98 & $16.94 * *$ & $19.27 * *$ & 87.67 & $19.01 * *$ \\
\hline $\mathrm{L} 28 \times \mathrm{L} 93$ & $113.33^{* *}$ & 17.00 & $100.00^{* *}$ & $46.67^{* *}$ & 2.33 & $22.22 * *$ & $-2.64 * *$ & -0.65 & $-6.43^{* *}$ & $20.18^{* *}$ & 4.09 & $14.54^{* *}$ \\
\hline $\mathrm{L} 28 \times \mathrm{L} 110$ & $55.56^{* *}$ & 5.00 & $40.00^{* *}$ & $17.65^{* *}$ & 3.00 & $11.11^{* *}$ & $25.25^{* *}$ & 7.42 & $21.13^{* *}$ & $19.13^{* *}$ & 20.23 & $18.01 * *$ \\
\hline L12 $\times$ L93 & $77.78^{* *}$ & 3.50 & $45.45^{* *}$ & $53.85^{* *}$ & 7.00 & $42.86^{* *}$ & $30.24 * *$ & 4.00 & $21.08^{* *}$ & $24.52 * *$ & 4.76 & $18.42 * *$ \\
\hline $\mathrm{L} 12 \times \mathrm{L} 110$ & $71.43^{* *}$ & 15.00 & $63.64^{* *}$ & $86.67^{* *}$ & 13.00 & $75.00^{* *}$ & $19.61^{* *}$ & 170.00 & $19.47^{* *}$ & $22.50^{* *}$ & 31.00 & $21.61 * *$ \\
\hline $\mathrm{L} 93 \times \mathrm{L} 110$ & $100.00^{* *}$ & 5.67 & $70.00 * *$ & $57.14^{* *}$ & 4.00 & $37.50^{* *}$ & $26.18^{* *}$ & 3.52 & $17.44 * *$ & $32.27 * *$ & 5.49 & $24.93 * *$ \\
\hline LSD $5 \%$ & 0.83 & & 0.96 & 0.78 & & 0.90 & 0.22 & & 0.25 & 0.22 & & 0.26 \\
\hline LSD $1 \%$ & 1.11 & & 1.28 & 1.04 & & 1.20 & 0.29 & & 0.34 & 0.30 & & 0.34 \\
\hline
\end{tabular}

Note: P refers to relative potency of the gene set; *,** refers to significant at $5 \%$ and highly significant at $1 \%$, respectively

Table 10d. Relative heterosis (MP) and heterbeltiosis (BP) as well as potence ratio (P) of $15 \mathrm{~F}_{1}$ cross combinations for seed weight per plant and seed oil content under normal irrigation $(\mathrm{N})$ and water stress conditions (S) in 2019 season

\begin{tabular}{|c|c|c|c|c|c|c|c|c|c|c|c|c|}
\hline \multirow{3}{*}{ Crosses } & \multicolumn{6}{|c|}{ Seed weight per plant } & \multicolumn{6}{|c|}{ Seed oil content } \\
\hline & \multicolumn{3}{|c|}{$\mathbf{N}$} & \multicolumn{3}{|c|}{$\mathbf{S}$} & \multicolumn{3}{|c|}{$\mathbf{N}$} & \multicolumn{3}{|c|}{$\mathbf{S}$} \\
\hline & MP & $\mathbf{P}$ & BP & MP & $\mathbf{P}$ & BP & MP & $\mathbf{P}$ & BP & MP & $\mathbf{p}$ & BP \\
\hline L95 × L92 & $-4.57 *$ & -0.28 & $-18.05^{* *}$ & $-17.83^{* *}$ & -0.76 & $-33.50 * *$ & -0.26 & -0.07 & $-3.69^{* *}$ & $10.64 * *$ & 2.48 & $6.08^{* *}$ \\
\hline $\mathrm{L} 95 \times \mathrm{L} 28$ & $25.84^{* *}$ & 11.50 & $23.08^{* *}$ & $42.21^{* *}$ & 3.82 & $28.06^{* *}$ & $-2.46^{* *}$ & -1.49 & $-4.04 * *$ & $-3.60 * *$ & -0.89 & $-7.33 * *$ \\
\hline $\mathrm{L} 95 \times \mathrm{L} 12$ & $16.23^{* *}$ & 15.52 & $15.03^{* *}$ & $47.07 * *$ & 74.01 & $46.14 * *$ & $6.31 * *$ & 2.68 & $3.87 * *$ & $2.66^{* *}$ & 0.67 & -1.27 \\
\hline L95 × L93 & $4.19^{*}$ & 0.82 & -0.87 & $28.97 * *$ & 1.78 & $10.90 * *$ & 0.18 & 0.78 & -0.05 & $2.12 * *$ & 0.42 & $-2.84 * *$ \\
\hline $\mathrm{L} 95 \times \mathrm{L} 110$ & $15.76^{* *}$ & 1.71 & $6.00^{*}$ & $28.28 * *$ & 1.62 & $9.16^{* *}$ & $4.51 * *$ & 4.76 & $3.52 * *$ & $5.89 * *$ & 1.25 & 1.11 \\
\hline $\mathrm{L} 92 \times \mathrm{L} 28$ & $8.89^{* *}$ & 0.48 & $-8.22 * *$ & $12.81^{* *}$ & 1.00 & -0.04 & $3.20 * *$ & 1.67 & 1.26 & $7.54 * *$ & 28.30 & $7.26^{* *}$ \\
\hline L92 × L12 & $11.11 * *$ & 0.72 & -3.75 & $39.19 * *$ & 1.62 & $12.10 * *$ & $12.90 * *$ & 10.72 & $11.56^{* *}$ & $9.85^{* *}$ & 31.62 & $9.51 * *$ \\
\hline L92 × L93 & -1.40 & -0.12 & $-11.53^{* *}$ & $26.16^{* *}$ & 3.46 & $17.28^{* *}$ & $6.94 * *$ & 2.09 & $3.50 * *$ & $8.71 * *$ & 10.68 & $7.83^{* *}$ \\
\hline $\mathrm{L} 92 \times \mathrm{L} 110$ & $32.50 * *$ & 4.42 & $23.42 * *$ & $39.67 * *$ & 6.28 & $31.37 * *$ & $4.52 * *$ & 1.00 & 0.02 & $8.30^{* *}$ & 19.05 & $7.83^{* *}$ \\
\hline $\mathrm{L} 28 \times \mathrm{L} 12$ & $53.30^{* *}$ & 16.19 & $48.42 * *$ & $75.58^{* *}$ & 6.47 & $57.21 * *$ & $-2.31 * *$ & -3.27 & $-3.00^{* *}$ & 0.76 & 16.85 & 0.71 \\
\hline $\mathrm{L} 28 \times \mathrm{L} 93$ & $36.98 * *$ & 5.04 & $27.61 * *$ & $45.52 * *$ & 8.54 & $38.16^{* *}$ & $2.29 * *$ & 1.62 & 0.87 & $5.31 * *$ & 4.91 & $4.19 * *$ \\
\hline $\mathrm{L} 28 \times \mathrm{L} 110$ & $20.76^{* *}$ & 1.82 & $8.37^{* *}$ & $32.84 * *$ & 4.99 & $24.65^{* *}$ & $3.62 * *$ & 1.40 & 1.01 & $7.30 * *$ & 10.40 & $6.55^{* *}$ \\
\hline $\mathrm{L} 12 \times \mathrm{L} 93$ & $17.90 * *$ & 4.41 & $13.30 * *$ & $30.47 * *$ & 1.80 & $11.60^{* *}$ & -1.01 & -0.48 & $-3.07 * *$ & 0.36 & 0.32 & -0.76 \\
\hline $\mathrm{L} 12 \times \mathrm{L} 110$ & $7.37 * *$ & 0.90 & -0.74 & $26.27^{* *}$ & 1.45 & $6.90 *$ & $-2.51 * *$ & -0.76 & $-5.62 * *$ & -0.59 & -0.80 & -1.33 \\
\hline $\mathrm{L} 93 \times \mathrm{L} 110$ & $11.79 * *$ & 2.85 & $7.36^{* *}$ & $13.60 * *$ & 10.85 & $12.20 * *$ & $2.10 * *$ & 1.78 & 0.91 & $9.40^{* *}$ & 24.76 & $8.99 * *$ \\
\hline LSD 5\% & 4.02 & & 4.64 & 4.68 & & 5.41 & 1.40 & & 1.62 & 1.44 & & 1.66 \\
\hline LSD $1 \%$ & 5.38 & & 6.21 & 6.27 & & 7.24 & 1.87 & & 2.16 & 1.92 & & 2.22 \\
\hline
\end{tabular}

Note: P refers to relative potency of the gene set; *,** refers to significant at $5 \%$ and highly significant at $1 \%$, respectively

\section{3-Hayman numerical and graphical analysis}

\section{3-1-Adequacy of simple additive-dominance model}

The validity of the additive-dominance model was discovered through three tests, which differed from partially to full adequate (Table 11), hence that emphasized the need to complete the identification of genetic components and their ratios according to Hayman (1954b).

\section{3-2-Genetic components and their ratios}

A graphical analysis (Figures 1a, 1b, 2a, 2b, 3a, 3b, 4a, 4b, $5 \mathrm{a}, 5 \mathrm{~b}, 6 \mathrm{a}, 6 \mathrm{~b}, 7 \mathrm{a}, 7 \mathrm{~b}, 8 \mathrm{a}, 8 \mathrm{~b})$ revealed the regression line intercepted the covariance axis below the point of origin in fruiting zone length, number of branches per plant and seed weight per plant under both irrigation regimes, capsule length under NI, and seed oil content under WSC indicating that over-dominance was governed in the inheritance of 
these traits. This was referred through the average degree of dominance $\left(\mathrm{H}_{1} / \mathrm{D}\right)^{0.5}$ (Table 12$)$, which had values more than unity for these traits. However, the other cases take the opposite direction. This result corroborates with the findings of Fahmy et al. (2015) and Abd EL-Satar et al. (2016), who found that over-dominance had the major role in the inheritance of most studied traits.

The significance of additive (a) and non-additive (b) effects in Jones (1965) analysis (Tables 6 and 7) and additive (D) and two dominance types in Hayman (1954b) analysis (Table 12) indicated the both additive and non-additive genetic components played a major role in the inheritance of all studied traits under both irrigation regimes.

However, the additive gene action was preponderant in the gene expression of most studied traits under both irrigation regimes and their combined analysis as verified by baker ratio and $(\mathrm{a} / \mathrm{b})$ ratio of Jones method.

This was further verified through medium narrowsense heritability (Table 12) for most studied traits under both irrigation regimes. These finding are in line with the results of Fahmy et al. (2015) and Abd EL-Satar et al. (2016), they found that narrow sense heritability was moderate for seed yield and most yield component traits. Hence, maximizing improvement of most studied traits can be achieved through selection of promising segregates in early generation. $\mathrm{H}_{1}$ and $\mathrm{H}_{2}$ dominance types considerable differed (Table 12) for all studied traits under both irrigation regimes. This difference was a result of an unequal sharing of dominant and recessive genes in the used parents, which was also proved by the $\mathrm{H}_{2} / 4 \mathrm{H}_{1}$ ratio that was less than 0.25 (Table 12) for all studied traits. The F value (Table 12) had positive sign for most studied traits, indicated that the occurrence of recessive alleles was lesser than that of the dominant alleles in the parents, and this was further verified through the ratio of $K_{D} / K_{R}$, which was more than unity under both irrigation regimes for most cases. The ratio of $\mathrm{h}^{2} / \mathrm{H}_{2}$ (Table 12) ranged from one to two pairs, which refers to the number of gene pairs governing in the inheritance of studied traits, confirmed that one to two pairs of dominant genes controlling the inheritance of all studied traits under both irrigation regimes. Same results were obtained by Fahmy et al. (2015).

\section{5-Distribution of dominant and recessive genes among the parents}

Parental sesame genotypes widely scattered in the $\mathrm{Wr}-\mathrm{Vr}$ graphical analysis (Figures 1a, 1b, 2a, 2b, 3a, 3b, 4a, 4b, 5a, $5 \mathrm{~b}, 6 \mathrm{a}, 6 \mathrm{~b}, 7 \mathrm{a}, 7 \mathrm{~b}, 8 \mathrm{a}, 8 \mathrm{~b})$ for all studied traits under both irrigation regimes, this confirmed their genetic diversity.

The most dominant genes were detected in the parents L93, L28 and L95 under NI and L93 under WSC for days to $50 \%$ flowering, L92 and L12 under both irrigation regimes for plant height, L93 and L12 under both irrigation regimes for fruiting zone length, L92 and L95 under NI and L92 and L12 under WSC for capsules length, L92 and L12 under NI and L28 and L93 under WSC for number of branches per plant, L93 and L110 under NI and L93 and L92 under WSC for 1000-seed weight, L95 and L93 under NI and L93 and L110 under WSC for seed weight per plant and L93 and L110 under NI and L28 and L93 under WSC, as they located closed to the origin of regression graph. However, the recessive genes were observed in L12 under both irrigation regimes for days to $50 \%$ flowering, L110 under both irrigation regimes for plant height, L28 under NI and L92 under WSC for fruiting zone length, L28 under both irrigation regimes for capsules length, L95 under both irrigation regimes

Table 11. Adequacy test of the data for additive-dominance model for all studied traits under normal irrigation $(\mathrm{N})$ and water stress conditions $(\mathrm{S})$ in 2019 season

\begin{tabular}{|c|c|c|c|c|c|c|c|c|}
\hline \multirow[t]{2}{*}{ Traits } & \multirow[t]{2}{*}{$\mathbf{I}$} & \multicolumn{4}{|c|}{ Joint regression analysis } & \multicolumn{2}{|c|}{$\begin{array}{l}\text { Analysis of variance } \\
\text { of array }\end{array}$} & \multirow[t]{2}{*}{ Fitness } \\
\hline & & $\mathbf{t}^{2}$ & (b) $\pm \mathrm{SE}$ & $\mathbf{b}=\mathbf{0}$ & $b=1$ & $\mathbf{W r}+\mathbf{V r}$ & $\mathbf{W r}-\mathrm{Vr}$ & \\
\hline \multirow{2}{*}{ Days to $50 \%$ flowering } & $\mathrm{N}$ & NS & $0.12 \pm 0.27$ & $\mathrm{NS}$ & $*$ & $* *$ & $* *$ & Partially adequate mode \\
\hline & $\mathrm{S}$ & NS & $-0.09 \pm 0.28$ & NS & $*$ & $* *$ & $* *$ & Partially adequate mode \\
\hline \multirow{2}{*}{ Plant height } & $\mathrm{N}$ & NS & $0.17 \pm 0.42$ & NS & NS & $* *$ & $* *$ & Partially adequate mode \\
\hline & $\mathrm{S}$ & NS & $0.20 \pm 0.41$ & NS & NS & $* *$ & $* *$ & Partially adequate mode \\
\hline \multirow{2}{*}{ Fruiting zone length } & $\mathrm{N}$ & NS & $0.77 \pm 0.31$ & NS & NS & $* *$ & $* *$ & Partially adequate mode \\
\hline & $\mathrm{S}$ & NS & $0.33 \pm 0.22$ & NS & $*$ & $* *$ & $* *$ & Partially adequate mode \\
\hline \multirow{2}{*}{ Capsules length } & $\mathrm{N}$ & NS & $0.61 \pm 0.27$ & NS & NS & $* *$ & $* *$ & Partially adequate mode \\
\hline & $\mathrm{S}$ & NS & $0.21 \pm 0.30$ & NS & NS & $* *$ & $* *$ & Partially adequate mode \\
\hline \multirow{2}{*}{$\begin{array}{l}\text { Number of branches per } \\
\text { plant }\end{array}$} & $\mathrm{N}$ & NS & $0.50 \pm 0.19$ & NS & NS & $* *$ & $* *$ & Partially adequate mode \\
\hline & $\mathrm{S}$ & NS & $0.32 \pm 0.23$ & NS & $*$ & $* *$ & $* *$ & Partially adequate mode \\
\hline \multirow{2}{*}{1000 -seed weight } & $\mathrm{N}$ & NS & $0.18 \pm 0.32$ & NS & NS & $* *$ & $* *$ & Partially adequate mode \\
\hline & $\mathrm{S}$ & NS & $0.06 \pm 0.36$ & NS & NS & $* *$ & $* *$ & Partially adequate mode \\
\hline \multirow{2}{*}{ Seed weight per plant } & $\mathrm{N}$ & NS & $0.59 \pm 0.24$ & NS & NS & $* *$ & $* *$ & Partially adequate mode \\
\hline & $\mathrm{S}$ & NS & $0.43 \pm 0.28$ & NS & NS & NS & NS & Fully adequate model \\
\hline \multirow{2}{*}{ Seed oil content } & $\mathrm{N}$ & NS & $-0.24 \pm 0.25$ & NS & $* *$ & $* *$ & $* *$ & Partially adequate mode \\
\hline & $\mathrm{S}$ & NS & $1.06 \pm 0.38$ & $*$ & NS & $* *$ & $* *$ & Partially adequate mode \\
\hline
\end{tabular}

Note: I: irrigation regimes; b: Regression-coefficient; Wr: covariance; Vr: variance.*, ** refers to significant at 5\% and highly significant at $1 \%$, respectively 
Table 12. Components of the genetic variance and their ratios (Hayman 1954b) for all studied traits under normal irrigation (N) and water stress conditions (S) in 2019 season

\begin{tabular}{|c|c|c|c|c|c|c|c|c|c|}
\hline Parameter & I & $\begin{array}{c}\text { Days } \\
\text { to } 50 \% \\
\text { flowering } \\
\end{array}$ & $\begin{array}{l}\text { Plant } \\
\text { height }\end{array}$ & $\begin{array}{l}\text { Fruiting } \\
\text { zone } \\
\text { length } \\
\end{array}$ & $\begin{array}{l}\text { Capsules } \\
\text { length }\end{array}$ & $\begin{array}{c}\text { Number of } \\
\text { branches per } \\
\text { plant }\end{array}$ & $\begin{array}{l}\text { 1000-seed } \\
\text { weight }\end{array}$ & $\begin{array}{c}\text { Seed } \\
\text { weight per } \\
\text { plant } \\
\end{array}$ & $\begin{array}{l}\text { Seed oil } \\
\text { content }\end{array}$ \\
\hline \multirow{2}{*}{$\mathrm{D}$} & $\mathrm{N}$ & 8.31 & $275.78 * *$ & $88.26 * *$ & $0.09 *$ & 1.02 & 0.12 & $21.03 * *$ & 1.92 \\
\hline & $\mathrm{S}$ & $7.12 *$ & $159.51 * *$ & 20.23 & 0.04 & 0.42 & 0.05 & $15.80 * *$ & $3.12 * *$ \\
\hline \multirow{2}{*}{$\mathrm{F}$} & $\mathrm{N}$ & 6.29 & 364.43 & -18.74 & -0.06 & 0.89 & -0.23 & 14.19 & 1.52 \\
\hline & $\mathrm{S}$ & 0.85 & 191.75 & -26.11 & 0.02 & 0.71 & -0.05 & 3.74 & 1.92 \\
\hline \multirow{2}{*}{$\mathrm{H}_{1}$} & $\mathrm{~N}$ & $81.92 * *$ & $864.57 * *$ & $446.07 * *$ & $0.45 * *$ & $5.70^{* *}$ & $1.06^{* *}$ & $85.79 * *$ & $11.60 * *$ \\
\hline & $\mathrm{S}$ & $51.08 * *$ & $515.27 * *$ & $209.77 * *$ & $0.30^{*}$ & $3.53 * *$ & $0.65 * *$ & $80.76 * *$ & $16.47^{* *}$ \\
\hline \multirow{2}{*}{$\mathrm{H}_{2}$} & $\mathrm{~N}$ & $64.42 * *$ & $602.20 * *$ & $390.38 * *$ & $0.42 * *$ & $5.16^{* *}$ & $0.97 * *$ & $75.07 * *$ & $10.54 * *$ \\
\hline & $\mathrm{S}$ & $48.78 * *$ & $370.19 * *$ & $185.69 * *$ & $0.26^{*}$ & $2.97 * *$ & $0.64 * *$ & $74.78 * *$ & $13.14^{* *}$ \\
\hline \multirow{2}{*}{$\mathrm{h}^{2}$} & $\mathrm{~N}$ & $42.16^{* *}$ & $378.54^{*}$ & $911.77 * *$ & $0.69 * *$ & $13.79 * *$ & $1.80 * *$ & $82.34 * *$ & 3.33 \\
\hline & $\mathrm{S}$ & $21.64 * *$ & $234.78 *$ & $349.31 * *$ & $0.42 * *$ & $7.46^{* *}$ & $1.11^{* *}$ & $129.57 * *$ & $15.91^{* *}$ \\
\hline \multirow{2}{*}{$\left(\mathrm{H}_{1} / \mathrm{D}\right)^{0.5}$} & $\mathrm{~N}$ & 3.14 & 1.77 & 2.25 & 2.22 & 2.37 & 2.96 & 2.02 & 2.46 \\
\hline & $\mathrm{S}$ & 2.68 & 1.80 & 3.22 & 2.59 & 2.89 & 3.67 & 2.26 & 2.30 \\
\hline \multirow{2}{*}{$\mathrm{H}_{2} /{ }_{4} \mathrm{H} 1$} & $\mathrm{~N}$ & 0.20 & 0.17 & 0.22 & 0.23 & 0.23 & 0.23 & 0.22 & 0.23 \\
\hline & $\mathrm{S}$ & 0.24 & 0.18 & 0.22 & 0.22 & 0.21 & 0.24 & 0.23 & 0.20 \\
\hline \multirow{2}{*}{$\mathrm{K}_{\mathrm{D}} / \mathrm{K}_{\mathrm{R}}$} & $\mathrm{N}$ & 1.27 & 2.19 & 0.91 & 0.74 & 1.45 & 0.51 & 1.40 & 1.38 \\
\hline & $\mathrm{S}$ & 1.05 & 2.00 & 0.67 & 1.22 & 1.81 & 0.74 & 1.11 & 1.31 \\
\hline \multirow{2}{*}{$\mathrm{h}^{2} / \mathrm{H}_{2}$} & $\mathrm{~N}$ & 0.65 & 0.63 & 2.34 & 1.66 & 2.67 & 1.86 & 1.10 & 0.32 \\
\hline & $\mathrm{S}$ & 0.44 & 0.63 & 1.88 & 1.63 & 2.51 & 1.73 & 1.73 & 1.21 \\
\hline \multirow{2}{*}{$h^{2}$ (n.s) } & $\mathrm{N}$ & 0.38 & 0.36 & 0.45 & 0.46 & 0.19 & 0.47 & 0.29 & 0.20 \\
\hline & $\mathrm{S}$ & 0.26 & 0.37 & 0.42 & 0.31 & 0.14 & 0.26 & 0.29 & 0.39 \\
\hline \multirow{2}{*}{$\mathrm{H}^{2}$ (b.s) } & $\mathrm{N}$ & 0.99 & 0.99 & 1.00 & 0.97 & 0.94 & 0.98 & 0.91 & 0.91 \\
\hline & $\mathrm{S}$ & 0.99 & 0.99 & 0.99 & 0.95 & 0.90 & 0.97 & 0.88 & 0.94 \\
\hline
\end{tabular}

Note: I, irrigation regimes; *, significant when it exceeds 1.96 after dividing it by its standard error; $* *$, is tested by $\mathrm{t}$ test at $\mathrm{n}-2$ degrees of freedom after dividing it by its standard error. $\mathrm{D}=$ Additive variance, $\mathrm{F}=$ Relative frequency of dominant and recessive allels, $\mathrm{H}_{1}=\mathrm{Dominance}$ variance, $\mathrm{H}_{2}=$ Dominance variance, $\mathrm{h}^{2}=$ square of difference P vs. all, $\left(\mathrm{H}_{1} / \mathrm{D}\right)^{0.5}=$ Average degree of dominance, $\mathrm{H}_{2} / 4 \mathrm{H}_{1}=$ Proportion of dominance and recessive genes, $\mathrm{K}_{\mathrm{D}} / \mathrm{K}_{\mathrm{R}}=$ Proportion between dominant and recessive genes in all parents, $\mathrm{h}^{2} / \mathrm{H}_{2}=$ Number of effective factors, $\mathrm{h}^{2}$ (n.s) $=$ Narrow-sense heritability, $\mathrm{H}^{2}$ (b.s) $\stackrel{\mathrm{D}}{=}$ Broad-sense heritability

for number of branches per plant, L28 under NI and L12 and L95 under WSC for 1000-seed weight, L92 and L110 under NI and L92 and L12 under WSC for seed weight per plant and L12 under NI and L92 under WSC for seed oil content, as they located farthest from the origin of

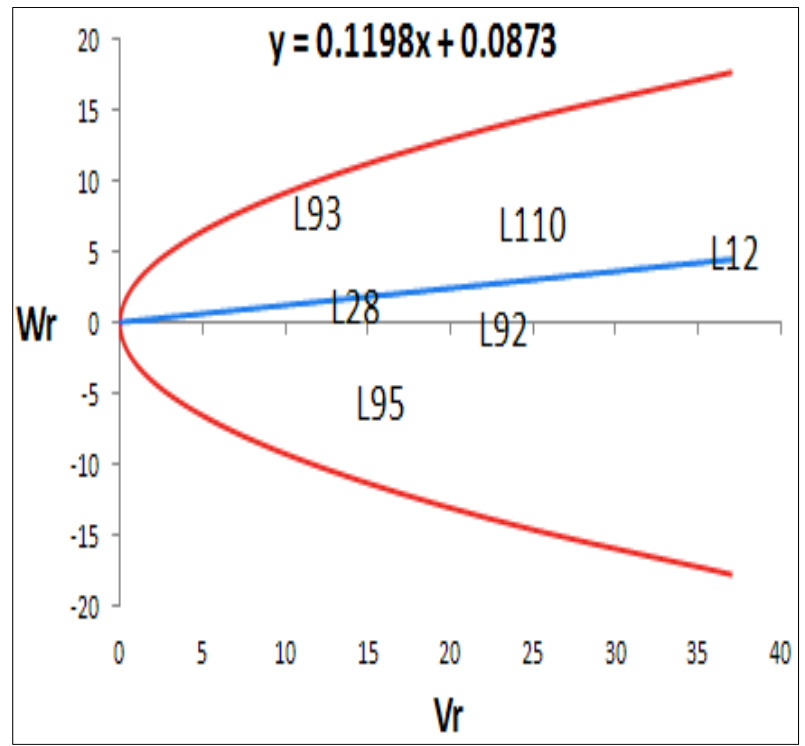

Fig. 1a: $\mathrm{Wr} / \mathrm{Vr}$ graphs for days to $50 \%$ flowering under NI regression graph. This result corroborates with the findings of Fahmy et al. (2015), who found that asymmetrical distribution of dominant and recessive genes in parental genotypes.

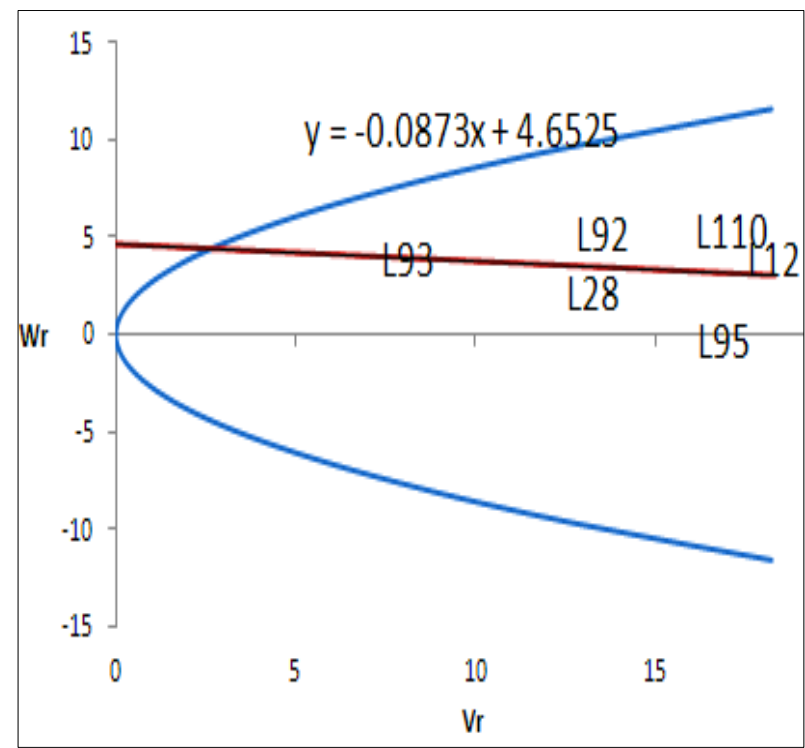

Fig. 1b: $\mathrm{Wr} / \mathrm{Vr}$ graphs for days to $50 \%$ flowering under WSC 


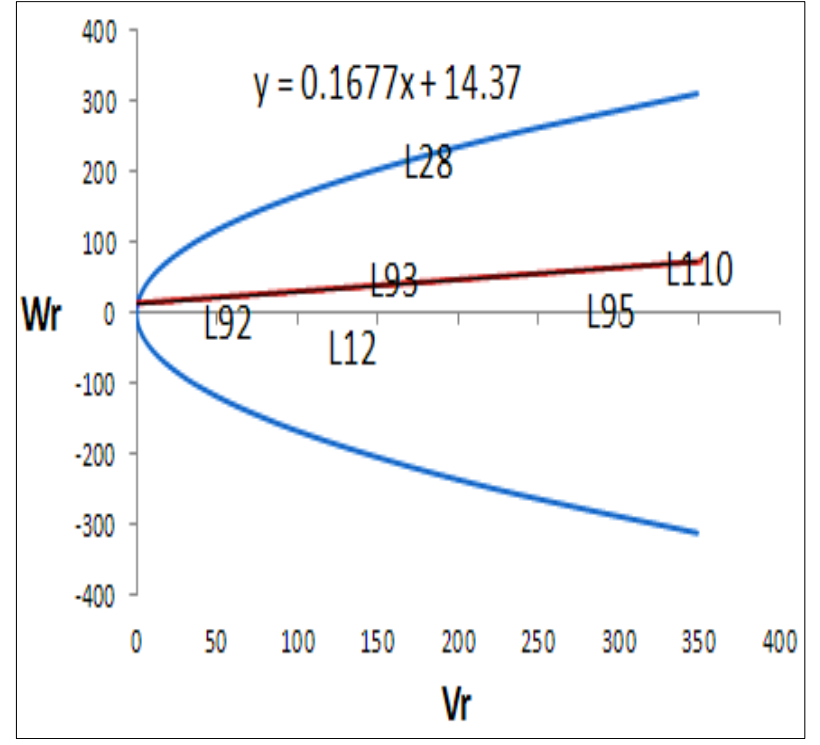

Fig. 2a: Wr/Vr graphs for plant height under NI

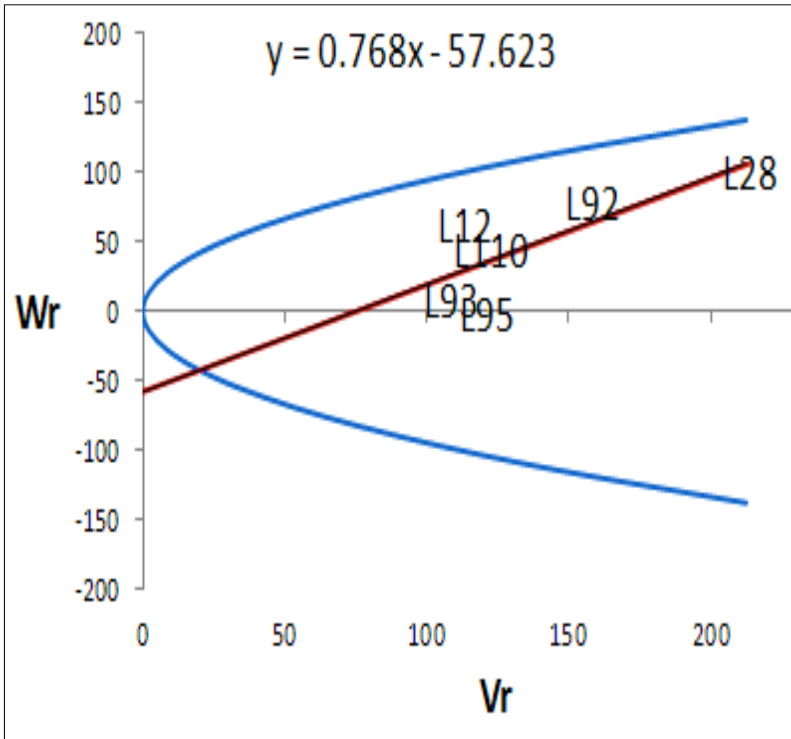

Fig. 3a: Wr/Vr graphs for fruiting zone length under NI

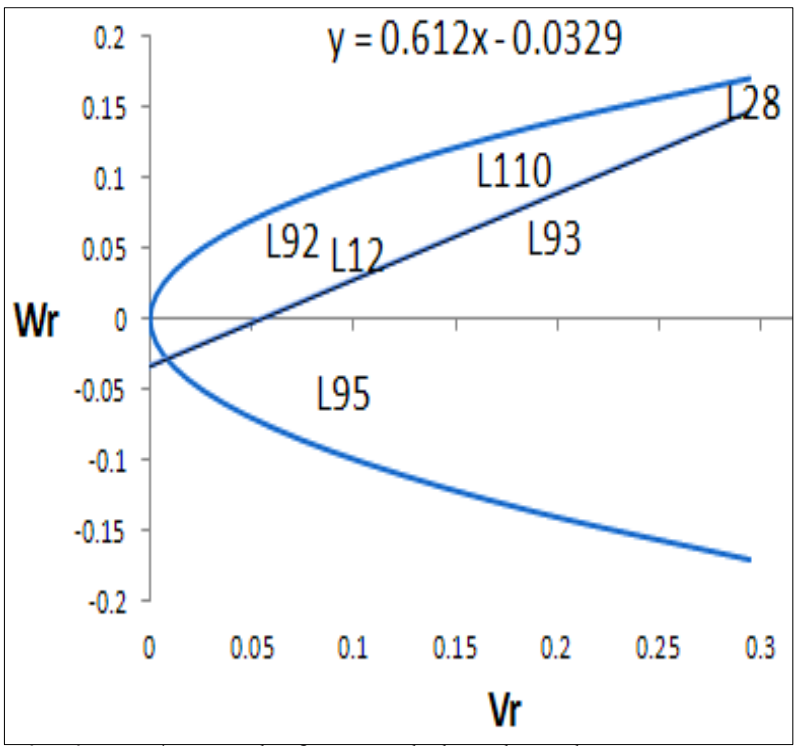

Fig. 4a: $\mathrm{Wr} / \mathrm{Vr}$ graphs for capsule length under NI

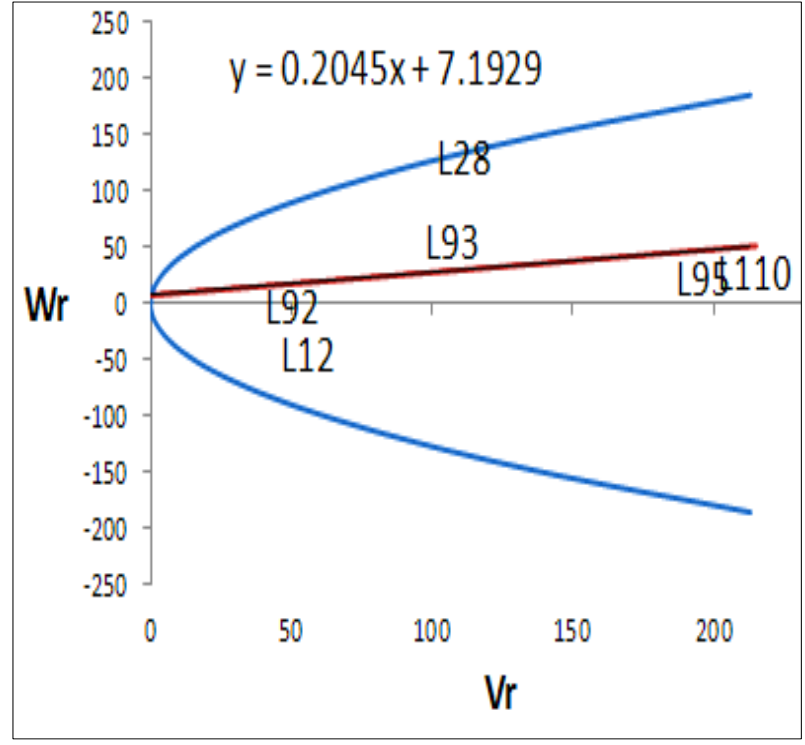

Fig. 2b: $\mathrm{Wr} / \mathrm{Vr}$ graphs for plant height under WSC

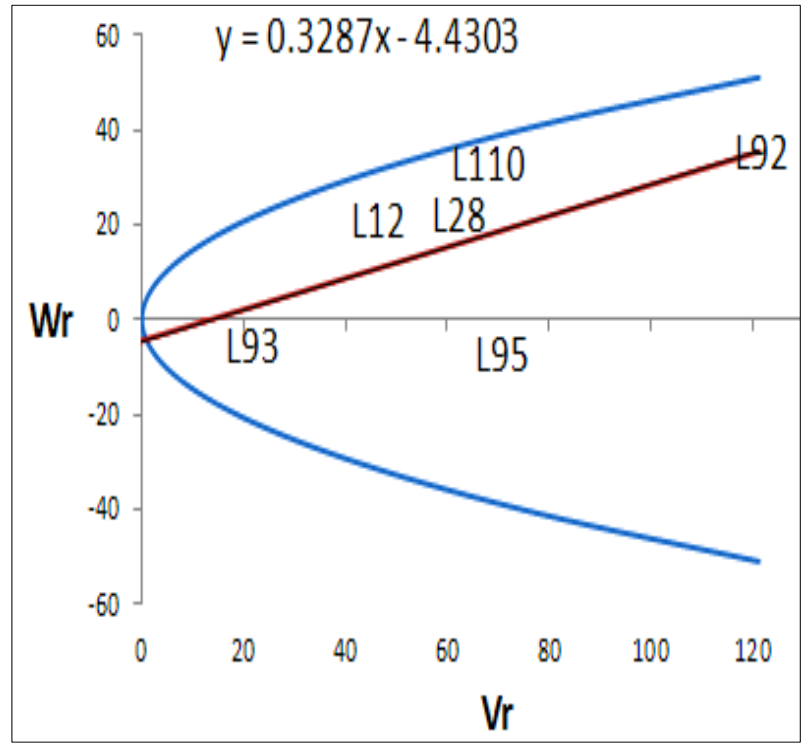

Fig. 3b: Wr/Vr graphs for fruiting zone length under WSC

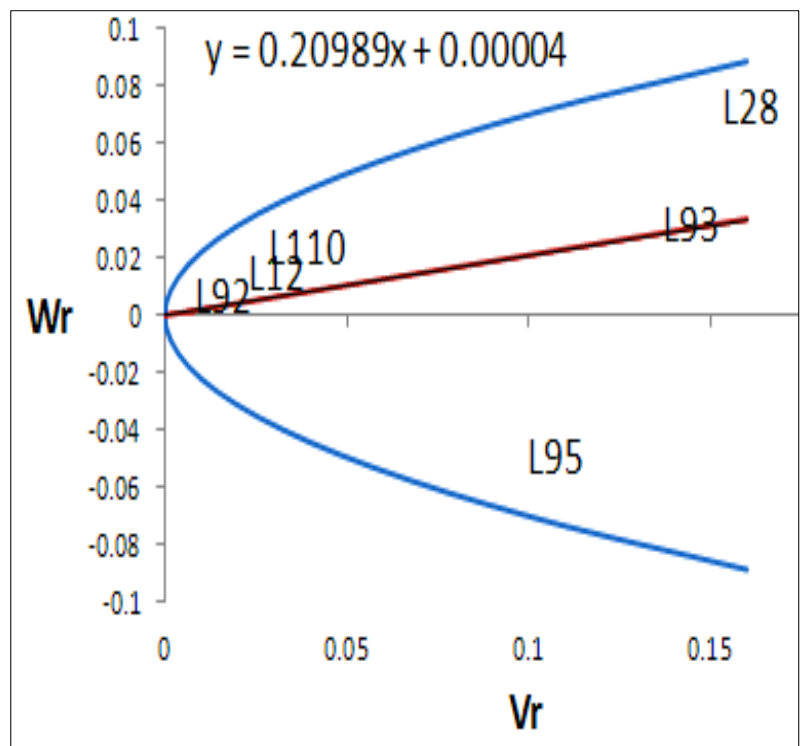

Fig. 4b: Wr/Vr graphs for capsule length under WSC 


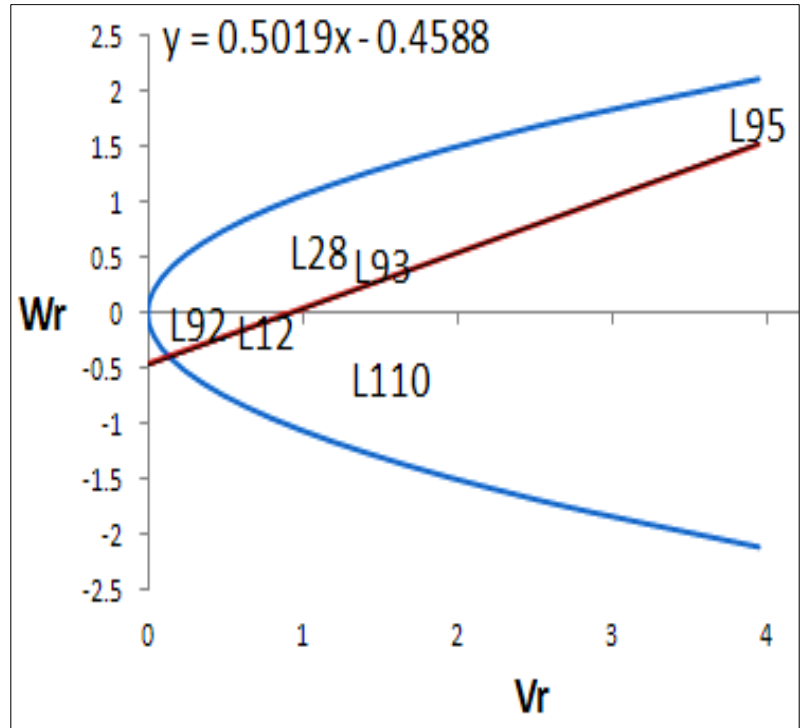

Fig. 5a: $\mathrm{Wr} / \mathrm{Vr}$ graphs for number of branches per plant under NI

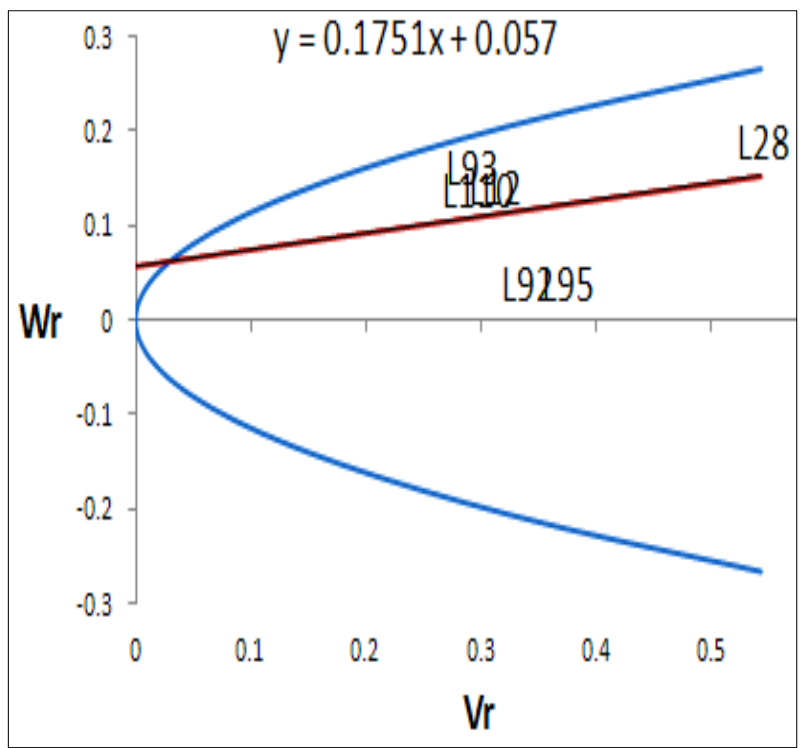

Fig. 6a: $\mathrm{Wr} / \mathrm{Vr}$ graphs for 1000-seed weight under NI

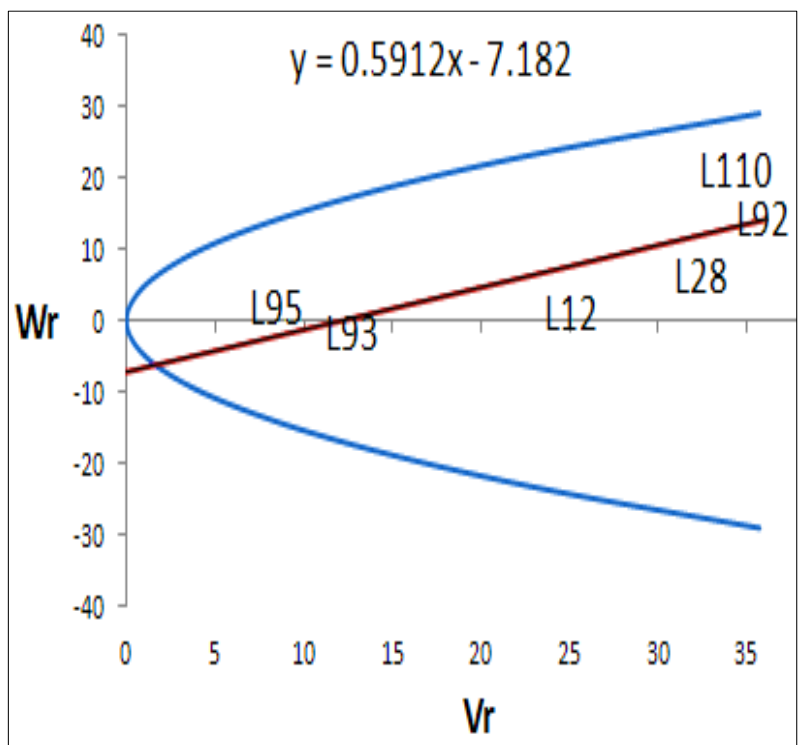

Fig. 7a: Wr/Vr graphs forseed weight per plant under NI

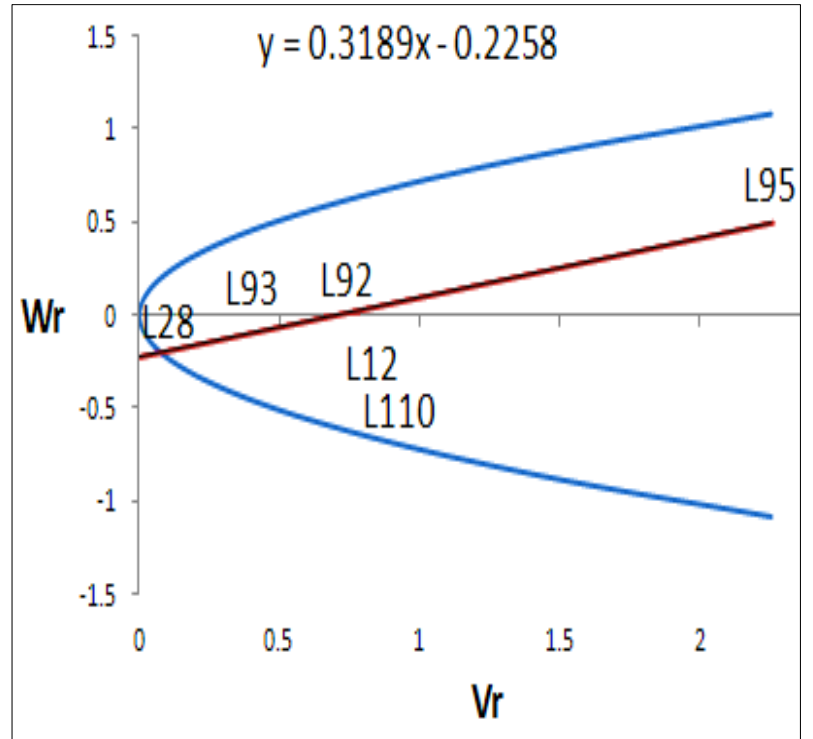

Fig. 5b: $\mathrm{Wr} / \mathrm{Vr}$ graphs for number of branches per plant under WSC

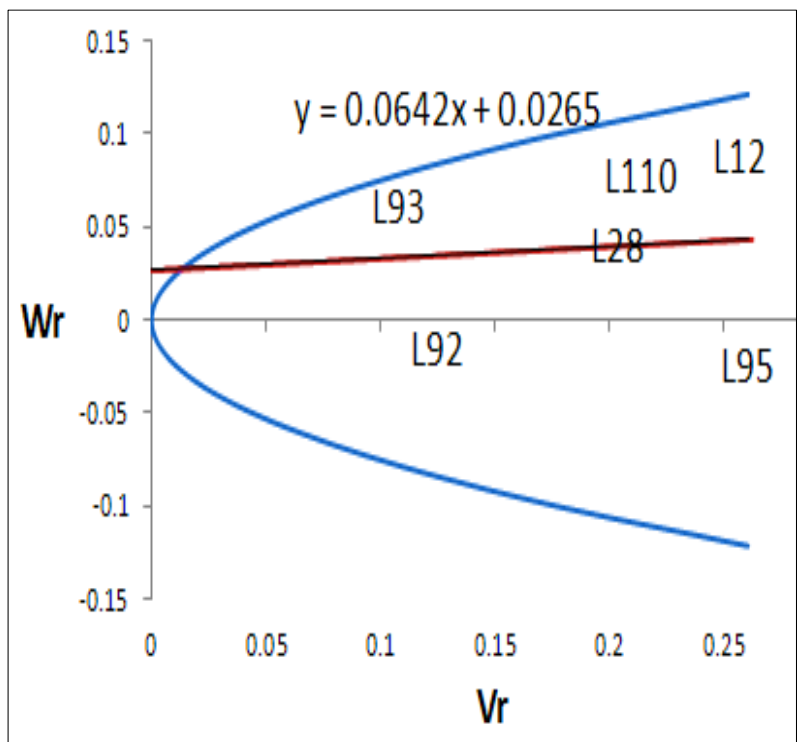

Fig. 6b: $\mathrm{Wr} / \mathrm{Vr}$ graphs for 1000-seed weight under WSC

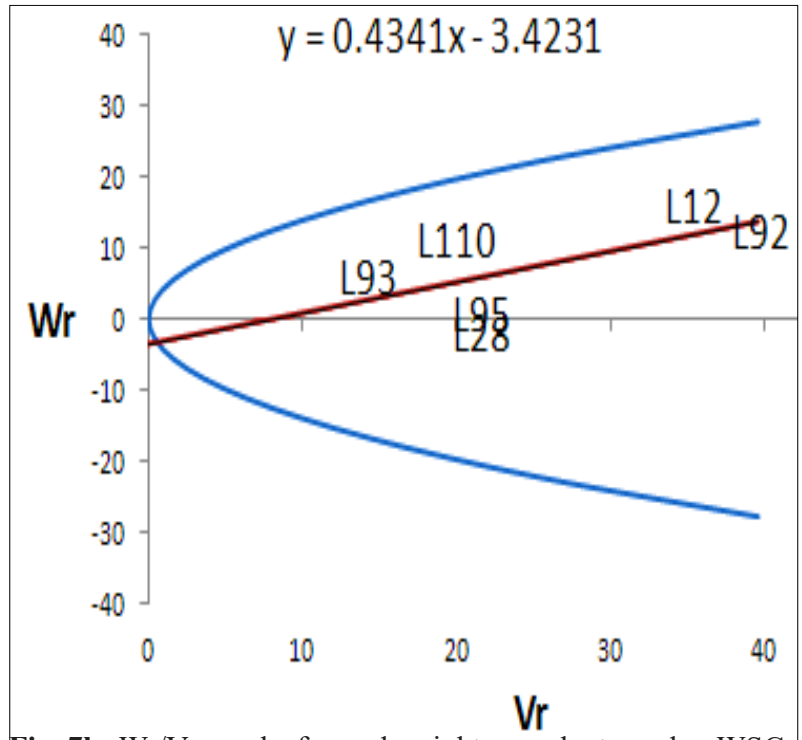

Fig. 7b: Wr/Vr graphs forseed weight per plant under WSC 


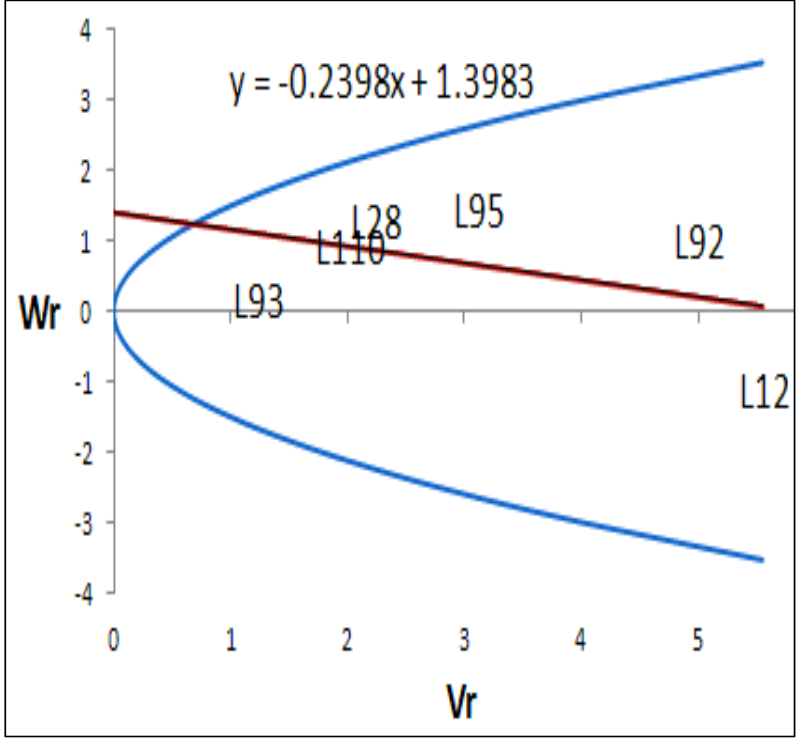

Fig. 8a: $\mathrm{Wr} / \mathrm{Vr}$ graphs for seed oil content under $\mathrm{NI}$

\section{Conclusion}

In conclusion, the differences due to parents and their $\mathrm{F}_{1}$ crosses were highly significant for seed yield and yield components under both irrigation regimes and their interactions with irrigation. Mean squares of two types of combining ability were highly significant for seed yield and yield components regimes and their interactions with irrigation. The best combiners for seed yield per plant and most of its component were observed in parents L92, L110 and their combination under both irrigation regimes. The additive gene action makes a greater contribution in the inheritance of most studied traits, that further confirmed by its significance and the value of average degree of dominance exceeding the unity. Narrow-sense heritability was high for most studied traits under both irrigation regimes. The most dominant genes carried on L95 and L93 under normal irrigation and L93 and L110 under water stress conditions for seed weight per plant, in contrary L92 and L110 under normal irrigation and L92 and L12 under water stress conditions for seed weight per plant possessed high concentration of recessive genes.

\section{References}

Abd EL-Satar, M. A., Ahmed Fadia, H. A., \& Elnenny, E. M. M. (2016). Line $\times$ tester analysis of yield and its components for high plant density tolerance in sesame. Egyptian Journal of Plant Breeding, 20(6), 1009-1034. Doi:10.12816/0046416

Association of Official Analytical Chemists (1990). Official Methods of analysis. $15^{\text {th }}$ Ed. Virginia, USA.

Azeez, M. A., \& Morakinyo, J. A. (2014). Combining ability studies and potential for oil quality improvement in sesame (Sesamum indicum L.). Journal of

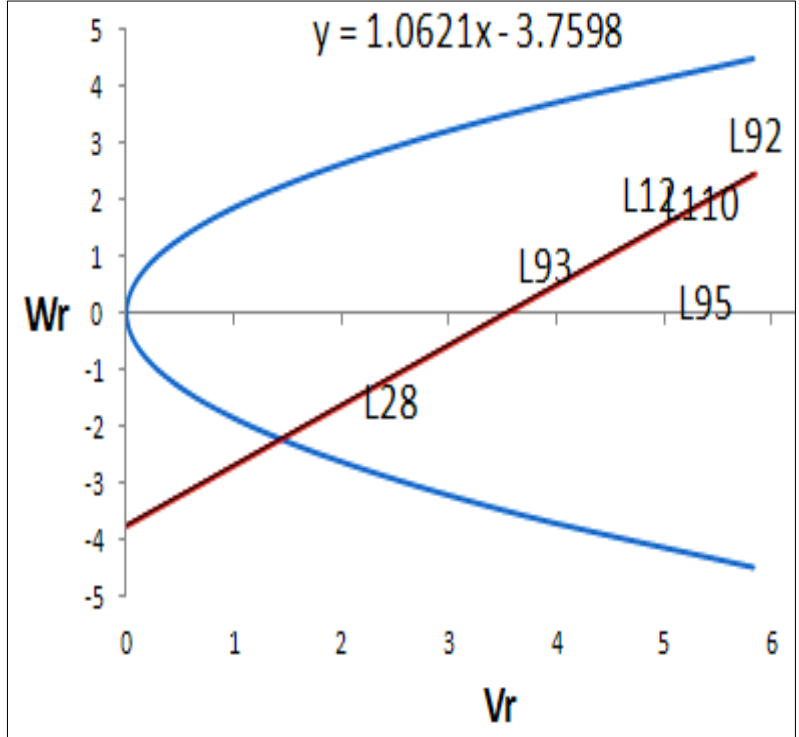

Fig. 8b: $\mathrm{Wr} / \mathrm{Vr}$ graphs for seed oil content under WSC

Agroalimentary Processes and Technologies, 20(1), $1-8$.

Baker, R. J. (1978). Issues in diallel analysis. Crop Science, 18(4), 533-536. https://doi.org/10.2135/ cropsci1978.0011183X001800040001x

Bhutia, N. D., Seth, T., Shende, Varun, D., Dutta, S., \& Chattopadhyay, A. (2014). Estimation of heterosis, dominance effect and genetic control of fresh fruit yield, quality and leaf curl disease severity traits of chilli pepper (Capsicum annuum L.). Scientia Horticulturae, 182, 47-55. https://doi.org/10.1016/j. scienta.2014.11.017

Fahmy, R. M., Abd EL-Satar, M. A., \& Hassan, T. H. A. (2015). Heterosis, combining ability and gene action for yield and its attributes of $\mathrm{F}_{1}$ crosses in sesame. Egyptian Journal of Plant Breeding, 19(3), 917-943.

Griffing, B. (1956). Concept of General and specific combining ability in relation to diallel cross system. Australian Journal of Biological Sciences, 9, 462-493.

Hayman, B. I. (1960). Theory and analysis of diallel crosses. Genetics, 45, 155-172.

Hayman, B. I. (1954a). The analysis of variance of diallel tables. Biometrics, 10, 235-244.

Hayman, B. I. (1954b). The theory and analysis of diallel crosses. Genetics, 39, 789-809.

Ismail, S., Khan, F. A., Mubarak, S., \& Kanwal, B. (2020). Heterosis in relation to combining ability studies in sesame (Sesamum indicum L.). Journal of Genetics, Genomics and Plant Breeding, 4(2), 68-75.

Jackson, M. L. (1973). Soil chemical analysis. PrenticeHall, Inc.; Englewood Cliffs. NJ, USA. 
Jeeva, G., Saravanan, K., \& Sowmiya, C. A. (2020). Assessment of combining ability and standard heterosis through diallel analysis in sesame (Sesamum indicum L.). Electronic Journal of Plant Breeding, 11(2), 386391.

Jinks, J. L. (1954). The analysis of continuous variation in a diallel cross of Nicotiana rustica varieties. Genetics, 39, 767-788.

Johnson, L. P. V., \& Aksel, R. (1964). The inheritance of malting quality and agronomic characters in a diallel cross of barley. Canadian Journal of Genetics and Cytology, 6, 178-200.

Jones, R. M. (1965). Analysis of variance of the half diallel table. Heredity, 20, 117-121.

Kearsy, M. J. (1965). Biometrical analysis of a random mating population: a comparison of five experimental designs. Heredity, 20, 205-235.

Mather, K., \& Jinks, J. L. (1982). Biometrical genetics, $3^{\text {rd }}$ edition. London Chapman and Hall.

Mather, K., \& Jinks, J. L. (1971). Biometrical genetics. Chapman and Ha $11 \mathrm{Ltd}$.

MS-EXCEL (2007). Microsoft software excel.

Ramesh, N., Shekhawat Macwana, S. S., Choudhary, R. $\&$ Patel, B. R. (2014). Line $\times$ tester analysis in sesame (Sesamum indicum L.). The Bioscan, 9(4), 1657-1660.

Salimath, P. M. \& Bahl, P. N. (1985). Heterosis and combining ability for earliness in chickpea (Cicer arietinum L.). Indian Journal of Genetics and Plant Breeding, 45, 97-100.

Steel, R. G., Torrie, J. H., \& Dickey, D. A. (1997). Principles and Procedures of Statistics. A Biometrical Approach $3^{\text {rd }}$ Edition. McGraw Hill book Co. Inc. New York, U.S.A.

Wigan, I. G. (1944). Balance and potence in natural populations. Journal of Genetic, 46, 150-60. 